Draft

March 2019

\title{
Unmixing the Mixed Questions: A Framework for Distinguishing Between \\ Questions of Fact and Questions of Law in Contractual Interpretation
}

\author{
Daniele Bertolini
}

University of British Columbia Law Review (Forthcoming, 2019)

In Sattva Capital Corp v Creston Moly Corp, the Supreme Court of Canada established that contractual interpretation generally involves questions of mixed fact and law subject to a standard of palpable and overriding error, unless an extricable error of law is identified. The Court confirmed and specified this holding in a number of subsequent decisions. The new approach to appellate deference has sparked criticism from various parties in the legal community. A tension has emerged between the Supreme Court shifting away from the historical common law approach to deference and the appellate courts' attempts to restore it. This article examines the theoretical foundations of this new case law development and proposes a methodological framework for distinguishing between questions of law and question of fact in contractual interpretation. The ultimate goal is to provide guidance on the choice of the appropriate standard of appellate review in this area. First, it is argued that the recent case law development introduced by the Supreme Court lacks rigorous analytical foundations and fails to provide adequate guidance on choosing the appropriate degree of deference on appeal. Second, it is contended that a useful methodological approach for distinguishing between questions of fact and questions of law is 1) to identify the cognitive task performed by the judge when adjudicating the contended issue, and 2) to assess the relative advantage of adjudicating actors in performing that cognitive task. Cognitive task refers to the type of judicial reasoning, or inferential activity, the judge performs when deciding an issue. 
Draft

March 2019

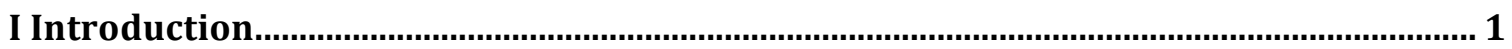

II The Evolution of the Jurisprudential Framework ............................................................ 7

A Pre-Sattva: Contextualism Versus Deferentialism ........................................................................

B Sattva And Its Progeny: Contextualism Involves Deferentialism .............................................11

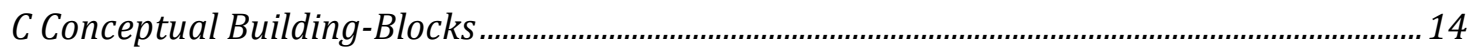

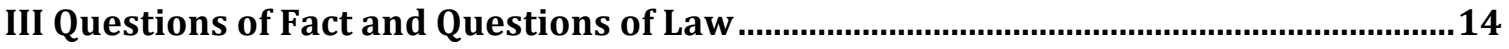

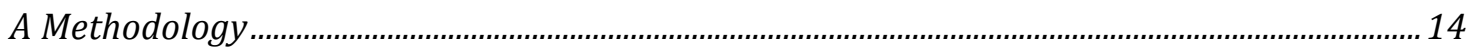

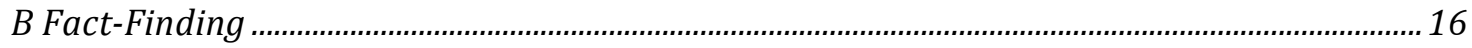

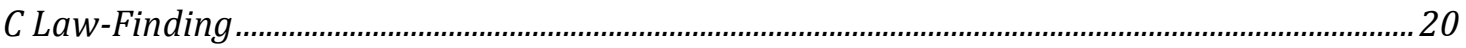

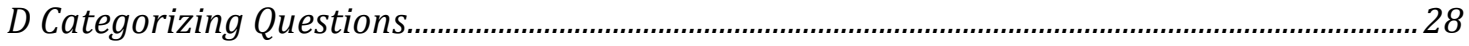

E Critique Of The Housen Categorization ……….............................................................................. 31

IV Categorizing Contractual Interpretation Issues ..........................................................

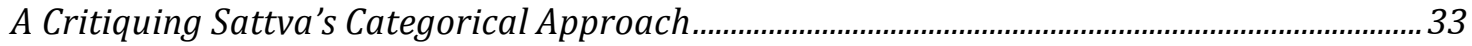

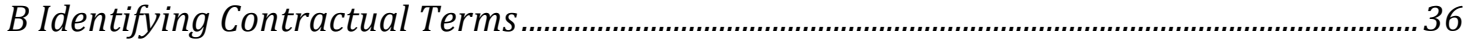

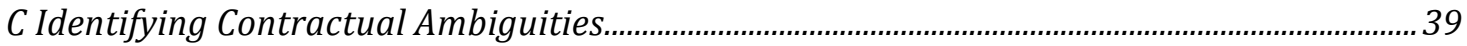

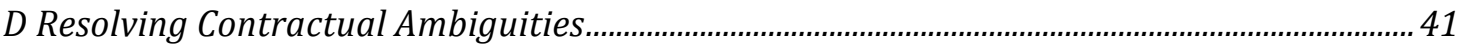

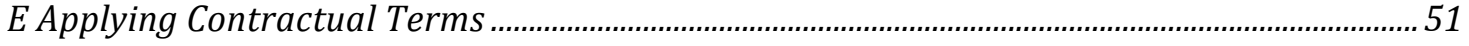

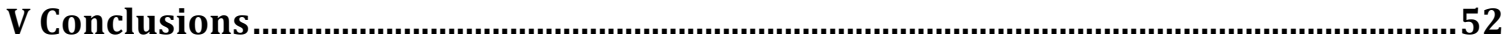


Draft

March 2019

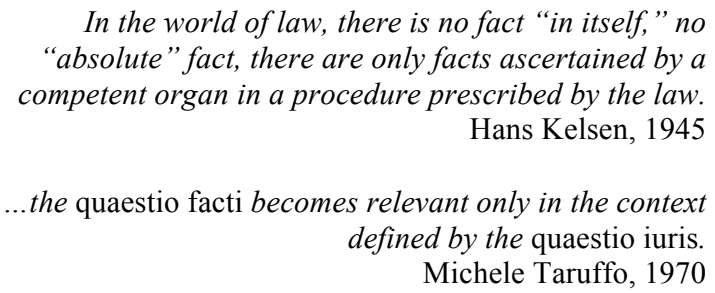

\section{Introduction}

In Sattva Capital Corp v Creston Moly Corp, ${ }^{1}$ the Supreme Court of Canada established that contractual interpretation generally involves questions of mixed fact and law subject to a standard of palpable and overriding error, except in rare circumstances where an extricable error of law is identified. The Court confirmed and further articulated this holding in Ledcor Construction Ltd $v$ Northbridge Indemnity Insurance Co ${ }^{2}$ and Teal Cedar Products Ltd $v$ British Columbia. ${ }^{3}$ This development constitutes a major change in the Canadian common law of contract. While the historical approach to contractual interpretation mandated that legal rights and obligations of the parties under a written contract were considered a question of law to be reviewed on appeal on a standard of correctness, the modern approach delineated in Sattva establishes that a deferential standard of review, as opposed to one of correctness, generally applies to issues of contractual interpretation.

The characterization of contractual interpretation as a question of mixed fact and law rather than a legal question has significant practical implications. First, it alters the institutional division of labour between the appellate courts and lower courts. Under the historical approach, an appellate court reviewing a trial judge's decision undertook a de novo analysis of the meaning of the contract, bound only by the trial judge' factual findings. Now, Sattva's deferential standard permits an appellate court to interfere with a trial judge's decision on a contractual interpretative issue only if the trial judge makes a palpable and overriding error or an extricable error of law. ${ }^{4}$ Second, the new approach to deference limits the availability of appellate review in contractual interpretation disputes. After Sattva, the party seeking to overturn the trial judge's decision must satisfy the court either that the trial judge made a palpable or overriding error, or that an extricable error of law can be identified from within what is initially characterized as a question of mixed fact and law. This significantly raises the burden of persuasion on both the party seeking

I am grateful to Pnina Alon-Shenker, Sari Graben, Gil Lan, and Avner Levin for their helpful observations and comments. I would also like to extend my appreciation to anonymous reviewers for providing very thoughtful and constructive suggestions leading to significant improvements. Errors and omissions remain my own.

${ }^{1} 2014$ SCC 53, [2014] 2 SCR 633 [Sattva]

2016 SCC 37, [2016] 2 SCR 23 [Ledcor]

32017 SCC 32, [2017] 1 SCR 688 [Teal]

${ }^{4}$ Supra note 1 at para 53. 
leave to appeal and the appellant party. ${ }^{5}$ Furthermore, in cases where the relevant statute permits appeal only on a point of law, the qualification of contractual interpretation as a mixed question defeats a court's appellate review jurisdiction, thereby making it virtually impossible to appeal a decision. ${ }^{6}$

Not surprisingly, the new approach to deference has sparked criticism from various parties in the legal community. Tension has emerged between the Supreme Court shifting away from the historical common law approach to deference and the appellate courts' attempts to restore it. In the aftermath of Sattva, both the British Columbia Court of Appeal and the Alberta Court of Appeal have refused to apply Sattva to appeals involving standard form contracts. ${ }^{7}$ In the Ledcor decision, the Supreme Court adjusted Sattva by recognizing that interpretation of a standard form contract may be a question of law to be reviewed on correctness. ${ }^{8}$ After Ledcor, however, a growing number of appellate courts' decisions introduced further exceptions to Sattva's deferential rule and identified a number of extricable errors of law in contractual interpretation. In Teal, the Supreme Court intervened to warn courts against this tendency to extend the notion of extricable errors of law. ${ }^{9}$ Appellate courts often disregard this caution, resulting in a growing body of case law addressing whether contractual interpretation raises questions of law or questions of mixed fact and law.

Many legal commentators criticize the Supreme Court's new approach to deference. A few authors have argued that there is no rational basis to accord deference to the trial judge's interpretation of the contract. ${ }^{10}$ Once the trier of fact has determined the facts in dispute, the exercise of interpreting the contract is essentially a legal one, with respect to which trial judges have no particular advantage over appellate courts. Several critical commentaries emphasize that the deferential rule laid down in Sattva inappropriately disrupts the division of labour between lower courts and appellate courts, ultimately undermining the error-correcting function of appellate courts. ${ }^{11}$ Other commentators have observed that Sattva's deferential standard erodes litigants' statutory right of appeal, ultimately subjecting litigants to the "luck of draw" or "the idiosyncrasies of the trier of fact." "12 A number of commentaries doubt the ability of the new jurisprudential

\footnotetext{
${ }^{5}$ Michael A Marion, The Sattva Case and its Importance to Domestic Arbitration in the Canadian Energy Industry (2014), online: <http://www.mondaq.com>; Geoff R Hall, Canadian Contractual Interpretation Law, 3d ed (Markham: Lexis Nexis Canada, 2016) at 150; Scott Bower, Russell Kruger \& Jonathan McDaniel, Canadian Contractual Interpretation Just Got More Difficult (2016), online: <https://www.bennettjones.com/>.

${ }^{6}$ This is especially relevant for parties to domestic arbitration agreements when the relevant statute permits appeal only on a "point of law." In such cases, parties wanting to ensure the availability of appellate review on contractual interpretation issues must expressly provide in their arbitration agreement that a question of mixed fact and law may constitute a ground of appeal.

${ }^{7}$ Angela Swan, Jakub Adamski \& Annie Na, Canadian Contract Law, 4th ed (Markham: Lexis Nexis Canada, 2018) at 719-20.

${ }^{8}$ Supra note 2 at para 24.

${ }^{9}$ Supra note 3 at para 45.

${ }^{10}$ Earl A Cherniak, "Sattva Revisited" (2015) 34 Adv J 6 at 8.

${ }^{11}$ See e.g., John Sopinka, Mark A Gelowitz \& W David Rankin, Sopinka and Gelowitz on the Conduct of an Appeal, 4th ed (Markham: Lexis Nexis Canada, 2018) at 126; Swan, supra note 7 at 735; Andrea M Bolieiro, "Ledcor and the Trouble with Taking a Categorical Approach to Standards of Review" (2017) 35:4 Adv J 35 at 37.

${ }^{12}$ Cherniak, supra note 10 at 8 (quoting Northwest Territories (Attorney General) v. Association des parents ayants droit de Yellowknife, 2015 NWTCA 21 at para 25). See also Sandra Corbett \& Ryan P Krushelnitzky, "Through the
} 
framework to ensure legal certainty and judicial efficiency. The conceptual indeterminacy of the notions of "mixed fact and law questions" and "extricable errors of law" creates the potential for increasing litigation over the appropriate standard of review and is likely to result in parties to a contractual dispute routinely arguing not only about the substantive merits of the appeal but also about the applicable standard of review. ${ }^{13}$ This, in turn, generates uncertainty on the availability of appellate review yet does not relieve a reviewing court from the necessity of properly characterizing the nature of the interpretation questions at issue. Finally, it is plausible the contextual approach to contractual interpretation will generate increasing demand for appellate review of trial judges' decisions, ${ }^{14}$ yet the deferential rule in Sattva seems likely to frustrate this growing demand.

These commentaries usefully (and correctly) illuminate crucial aspects of Sattva and its progeny, underlining the need for greater clarity and consistency on the appropriate standard of appellate review in contractual interpretation. However, while focusing on the practical implications of these cases, commentators have seldom engaged in an in-depth analysis of the conceptual foundations of the new approach to deference. Lacking a careful examination of the conceptual underpinnings of this new jurisprudential trend, the debate thus far fails to provide guidance on how to promote greater clarity and consistency on the appropriate standard of appellate review in contractual interpretation. This article examines the theoretical foundations of the Supreme Court's new approach to deference and proposes a methodological framework for distinguishing between questions of law and questions of fact in contractual interpretation. Based on the proposed framework it suggests an alternative categorization of contractual interpretation issues. The ultimate goal is to provide more coherent guidance on the choice of the appropriate standard of appellate review in this area.

This article's central thesis is twofold. First, it is argued that the recent case law development introduced by the Supreme Court lacks rigorous analytical foundations and therefore fails to provide adequate guidance on choosing the appropriate degree of deference on appeal. Rather than generalizing the deferential standard to all contractual interpretation issues and relegating correctness review to exceptional cases of extricable errors of law, a more sensible approach would be to distinguish between the various steps involved in the process of contractual interpretation and locate each step at the proper point on the fact-law spectrum. Second, it is contended that a useful methodological

Scratched Looking Glass: Sattva, Ledcor, Teal and Developments in the Law of Contract" (2017) 1 Ann Rev Civ Lit 379 at 404.

${ }^{13}$ Corbett, supra note 12 at 397 (“Contract law disputes may now begin, at least at the appellate level, to resemble administrative law disputes that engage in disputes over both the standard of review and the substantive merits"). See also Bower, supra note 5.

${ }^{14}$ That the adoption of contextual interpretation by trial judges increases the demand for appellate review is an empirical question that has not been investigated in the literature. However, it is plausible that, by expanding the evidentiary base considered when interpreting a contract, the contextualist approach adds to the potential for litigation; in turn, this may foster the propensity to appeal the trial judge's decision. The expansion of the evidentiary base increases the opportunity for diverging interpretations of the parties' contractual intent. In turn, this is likely to generate diverging expectations of private parties over the likely adjudication outcome. It is the prevailing opinion of law and economic scholars that diverging expectations regarding the adjudication outcome is one of the main drivers of the propensity to litigate. See Steven Shavell, Foundations of Economic Analysis of Law (Cambridge: Belknap Press, 2004) at 390 and 420 . 
approach for distinguishing between questions of fact and questions of law is 1) to identify the cognitive task performed by the judge when adjudicating the contended issue, and 2) to assess the relative advantage of adjudicating actors in performing that cognitive task. Cognitive task refers to the type of judicial reasoning, or inferential activity, the judge performs when deciding an issue. ${ }^{15}$ It is suggested here that the conceptual categories developed to explain the adjudicative reasoning provide useful insights into understanding and operationalizing the distinction between question of fact and questions of law.

It is widely recognized that the fact-law distinction is an allocative device used to distribute decision-making authority between appellate courts and trial judges. ${ }^{16} \mathrm{~A}$

\footnotetext{
${ }^{15}$ There is a vast array of literature examining both the nature of legal reasoning and the various types of inferential steps used by judges within the adjudication process. See e.g., Carlos Alchourrón \& Eugenio Bulygin, Normative systems (New York: Springer, 1971); Aulis Aarnio, On Legal Reasoning (Turku, Turku University Library:1977); Neil MacCormick, Legal Reasoning and Legal Theory (Oxford: Oxford University Press, 1978); Aleksander Peczenik, The Basis of Legal Justification (Lund, Sweden: A. Peczenik, 1983); Robert Alexy, A Theory Of Legal Argumentation: The Theory Of Rational Discourses As A Theory Of Legal Justification (Oxford: Clarendon, 1989); Aleksander Peczenik, On Law and Reason (Boston: Kluwer, 1989); Jerzy Wróblewski, The Judicial Application of Law (Dordrecht; Boston : Kluwer Academic Publishers, 1992); Aulis Aarnio \& Neil MacCormick, eds, Legal Reasoning (New York: New York University Press, 1992); Neil MacCormick, Rhetoric and the Rule of Law: A Theory of Legal Reasoning (Oxford: Oxford University Press, 2005); Jerzy Stelmach \& Bartosz Brozek, Methods of Legal Reasoning (Dordrecht: Springer, 2006); Pierluigi Chiassoni, Tecnica dell'Interpretazione Giuridica (The Technique of Legal Interpretation) (Bologna: Il Mulino, 2007); Alexander Larry \& Emily Sherwin, Demystifying Legal Reasoning (New York : Cambridge University Press, 2008); Giovanni Sartor, "Legal Concepts as Inferential Nodes and Ontological Categories" (2009) 17 Artificial Intelligence and Law 217; Douglas Walton, Legal Argumentation and Evidence (University Park, Pa.: Pennsylvania State University Press, 2010); Riccardo Guastini, Interpretare e Argomentare (Interpreting and Arguing) (Milan: Giuffre, 2011);

${ }^{16}$ The fact/law distinction is the subject of rich, long-lasting debate. See e.g., James B Thayer, "Law and Fact in Jury Trials" (1890) 4 Harv L Rev 147; Fabez Fox, "Law and Fact" (1898) 12 Harv L Rev 545; John Dickinson, Administrative Justice and the Supremacy of Law in Unites States (Cambridge: Harvard University Press, 1927) at 157-202; Helen Silving, "Law and Fact in the Light of the Pure Theory of Law" in Paul Sayre, ed, Interpretations of Modern Legal Philosophers: Essays in Honor of Roscoe Pound (New York: Oxford University Press, 1947); Arthur L Goodhart, "Appeals on Questions of Fact" (1955) 71 Law Q Rev 402; Louis L Jaffe, "Question of Law" (1955) 69 Harv L Rev 239; Louis L Jaffe, "Question of Fact" (1956) 69 Harv L Rev 1020; Ch Perelman and Ch Pebelman, "La Distinction Du Fait Et Du Droit Le Point De Vue Du Logicien" (1961) 15 Dialectica 601; W A Wilson, "A Note on Fact and Law" (1963) 26 Mod L Rev 21; Jerzy Wróblewski, "Facts in Law" (1973) 59 Archiv für Rechts-und Sozialphilosophie 161; Alida Wilson, "The Nature of Legal Reasoning: A Commentary with Special Reference to Professor MacCormick's Theory” (1982) 2 LS 269; John Jackson, "Questions of Fact and Questions of Law”, Robert S Summers, "Comments of Alan White's "Fact in the law"," Mark Ockleton Leeds, "Comments on John Jackson 'Questions of Fact \& Questions of Law'" in William Twining, ed, Facts in Law (Wiesbaden: Franz Steiner, 1983); Henry P Monaghan, "Constitutional Fact Review" (1985) 85 Colum L Rev 229; Michele Taruffo, "Value Judgments in the Judgment of Fact" (1985) 18 Archivium Iuridicum Cracoviense 45; Patrick Nerhot, "The Law and Its Reality" in Patrick Nerhot, ed, Law, Interpretation and Reality: Essays in Epistemology, Hermeneutics, and Jurisprudence (Boston: Kluwer, 1990) at 50-69; Csaba Varga, "The Mental Transformation of Facts into a Case" (1991) 77 Archiv für Rechts- und Sozialphilosophie 59; George C Christie, "Judicial Review of Finding of Fact" (1992) 87 Nw U L Rev 14; Richard D Friedman, "Standards of Persuasion and the Distinction Between Fact and Law" (1992) 86 Nw U L Rev 916; Mazzarese Tecla, "Dubbi Epistemologici sulle Nozioni di 'Quaestio Facti' and 'Quaestio Iuris"” (Epistemological Concerns on the Notions of 'Question of Fact' and 'Question of Law') (1992) 49 Rivista Internazionale di Filosofia del Diritto 294; Timothy Endicott, "Questions of Law" (1998) 114 Law Q Rev 292; Peter Tillers, "The Value of Evidence in Law" (1998) 39 N Ir Legal Q 167; William Twinning, "Narrative Generalizations in Argumentation about Questions of Fact" (1999) 40 S Tex L Rev 351; Ronald J Allen \& Michael S Pardo, "The Myth of the Law-Fact Distinction" (2003) 97 Nw U L Rev 1769; Pablo E Navarro \& Jorge L Rodriguez, Deontic Logic and Legal Systems (Cambridge: Cambridge University Press, 2014); Carlos E Alchourrón \& Eugenio Bulygin, "Limits of Logic and Legal Reasoning" in Carlos Bernal et al., ed, Essays in Legal Philosophy (Oxford: Oxford University Press, 2015) at 252-271; Emad H Atiq, "Legal Vs. Factual Normative Questions \& The True Scope Of Ring" (2018) 32 Notre Dame JL Ethics \& Pub Pol'y 47; Orlin Yalnazov, Precedent and Statute. Lawmaking in the Courts versus Lawmaking in Parliament (Wiesbaden: Springer Gabler, , 2018) at 87-110.
} 
variety of well-recognized policy reasons suggest assigning the primary responsibility for fact-finding to trial courts, while entrusting appellate courts with the primary role of delineating and refining legal rules. ${ }^{17}$ What remains the source of considerable debate is how to operationalize the distinction between questions of fact and questions of law. ${ }^{18}$ It is argued here that because the distinction is formulated for allocative purposes, it should be driven by a comparative institutional assessment of the relative advantages of trial judges and appellate courts in performing the various tasks involved in the adjudication process. The type of cognitive task performed by the judge in adjudicating interpretive issues provides a workable basis for conducting the comparative assessment that underpins the distinction between questions of fact and questions of law. Once the nature of the cognitive task involved in deciding an issue is identified, one can evaluate which institutional actor is better placed to perform that cognitive task.

The proposed methodology enhances the clarity and coherence of the fact/law distinction in contractual interpretation. ${ }^{19}$ The current case law grounds the distinction on the degree of generality of the issue being considered. ${ }^{20}$ However, the degree of generality is woefully incomplete as a controlling criterion for the allocation of power between the appellate court and the trial judge. To say the key difference between a question of law and a question of mixed fact and law is found in the degree of generality does not help in the least in probing the level of generality at which a question becomes a legal question of law. Not surprisingly, issues that do not fall squarely neither within the category of

\footnotetext{
${ }^{17}$ In Housen v Nikolaisen, 2002 SCC 33 [2002], 2 SCR 235, [Housen] at paras 15-17, the Supreme Court of Canada identifies three reasons for deferring to the factual findings of the trial judge: 1) limiting the number, length, and cost of appeals; 2) promoting the autonomy and integrity of trial proceedings, and 3) recognizing the expertise of the trial judge and her advantageous position. See also RD Gibbens, "Appellate Review of Findings of Fact" (1992) 13 Advocates' Q 445; Gavin Drewry, Louis Blom-Cooper, \& Charles Blake, The Court of Appeal (Oxford: Hart, 2007) at 20-30.

${ }^{18}$ See e.g., Jackson, supra note 16 at 87 (arguing that the distinction between the factual and normative aspects of the legal inquiry does not in fact correspond to the distinction between questions of fact and questions of law); Monaghan, supra note 16 (emphasizing the allocative nature of the distinction); Christie, supra note 16 (criticizing the usefulness of the distinction between 'law elaboration' and 'law application'); Mazzarese, supra note 16 at 299-302 (casting doubt on the very possibility of distinguishing between quaestio facti and quaestio iuris); Endicott, supra note 16 at 26-27 (arguing, " [A] question of application is a question of fact when it is capable of decision either way, and that it is a question of law when the law requires a decision one way"); Allen \& Pardo, supra note 16 (arguing there is no reasoned analytical distinction between law and fact); Atiq, supra note 16 (arguing that normative questions that are convention-independent - that is, that implicate fundamental moral norms - are reasonably classified as a question of fact, while normative questions that are convention-dependent are reasonably classified as a question of law).

${ }^{19}$ On the issue of the fact-law distinction in contractual interpretation, see William C Whitford, "The Role of the Jury in Contract Interpretation" (2001) Wis L Rev 931; Randall H Warner, "All Mixed Up about Mixed Questions" (2005) 7 J App Pr \& Pro 101; Gerard McMeel, The Construction of Contracts: Interpretation, Implication and Rectification (Oxford: Oxford University Press, 2007) at 56; Steven J Burton, Elements of Contract Interpretation (Oxford; Oxford University Press, 2009) at 152-155; Randall H Warner, "All Mixed Up About Contract: When is Contract Interpretation A Legal Question and When Is It a Fact Question?” (2010) 5 Va L \& Bus Rev 81; Kim Lewison, The Interpretation of Contracts, 5 edn, (London: Sweet and Maxwell, 2011) at 173-178. With respect to Canadian law, see Roger P Kerans \& Kim M Willey, Standards of Review Employed by Appellate Courts (Edmonton: Juriliber, 2006) at 142; Geoff R Hall, "Two Unsettled Questions in the Law of Contractual Interpretation: A Call to the Supreme Court of Canada," (2011) 50 Can Bus LJ 434; S Waddams, "Contractual Interpretation” (2015) 131 Law Q Rev 48 at 49-51; Cherniak, supra note 10; Hall, supra note 5 at 146-153; Bolieiro, supra note 11; Corbett, supra note 12; Sopinka, supra note 11 at 119-126; Swan, supra note 7 at 719-720 and 735-738.

${ }^{20}$ Canada (Director of Investigation and Research) $v$ Southam Inc. [1997] 1 SCR 748, 1 R.C.S. 748 [Southam] at para 37; Housen, supra note 17 at para 28 (quoting Southan para 37).
} 
factual questions nor within that of legal questions are lumped together into the catch-all category of "mixed" fact and law questions. This terminology denotes the inability of the classificatory framework to appreciate the structural differences between factual and legal issues. $^{21}$ The methodology proposed here demystifies the category of mixed questionsthere is no such thing as a question of mixed fact and law. There is rather a plurality of distinct cognitive exercises performed by judges within the adjudicative process. Certain tasks are conveniently left to the trier of fact; others are appropriately reviewed by the appellate court.

Focusing on the judicial cognitive task helps identify the troubling assumptions underlying Sattva's categorical statement that issues of contractual interpretation generally involve questions of mixed fact and law. In the Supreme Court's view, the contextualist approach to contractual interpretation, which suggests an inextricable intertwining of fact and law, mandates a deferential standard of appellate review. The suggested focus on the judicial cognitive task casts doubt on this assumption. While contractual interpretation amounts to a factual exercise in those systems that conceive the judge's role as that of ascertaining the parties' empirical intent at the moment of the execution of contract, it is far less clear that contractual intent can be properly qualified as a factual matter in systems (like the Canadian contract law) that conceptualize intent from the objective standpoint.

Finally, the focus on the judicial cognitive task reveals a further problematic aspect of the deferentialist approach. In laying down a general deferential standard of appellate review for contractual interpretation cases, the Court misleadingly refers to the process of contractual interpretation as an indistinct whole, without appropriately distinguishing its various components. ${ }^{22} \mathrm{~A}$ careful analysis of the various steps (and the underlying cognitive tasks) performed by the judge when interpreting a contract shows that while certain issues of contractual interpretation issues may be characterized as factual in nature, other aspects require no fact-finding.

This article is organized as follows. Section II briefly examines the recent historical evolution of Canadian case law regarding the nature of contractual interpretation and the appropriate standard of appellate review. The goal of this section is to identify the conceptual underpinnings of the Supreme Court's new approach to deference, which is examined in the remaining part of the paper. Section III provides a conceptual framework for examining the distinction between questions of fact and questions of law. This discussion, which draws on the philosophical analytical theory of judicial reasoning, identifies the various cognitive tasks involved in the judicial application of law and

\footnotetext{
${ }^{21}$ See Oliver W Holmes, The Common Law (New York: Dover Publications, 1991 [1881]) at 122; Endicott, supra note 16 at 8-9; Mike Madden, "Conquering the Common Law Hydra: A Probably Correct and Reasonable Overview of Current Standards of Appellate and Judicial Review" (2010) 36 Advocates' Q 269 at 284.

${ }^{22}$ In a widely quoted passage in Sattva, the Supreme Court recognizes extricable questions of law in contractual interpretation may include errors involving "the application of an incorrect principle, the failure to consider a required element of a legal test, or the failure to consider a relevant factor" (supra note 1 at para 53, quoting King $v$ Operating Engineers Training Institute of Manitoba Inc, 2011 MBCA 80, 270 Man R (2d) 63 [King] at para 21). However, without further examination of the nature of each of these steps, this recognition does nothing more than add to the uncertainty surrounding the identification of legal errors that could attract the correctness standard in contractual interpretation.
} 
characterizes them as either legal or factual in nature. This analysis targets certain critical aspects of the categorization of questions created in the seminal ruling in Housen. ${ }^{23}$ Section IV applies the proposed framework and criticisms to the area of contractual interpretation. The conceptual underpinnings of the Supreme Court's approach to deference are examined. It is demonstrated that the qualification of contractual interpretation as a question of mixed fact and law does not flow inexorably from the adoption by courts of a contextual approach to contractual interpretation. From this perspective, the discussion examines the various steps involved in contractual interpretation and characterizes them as either legal or factual in nature. The analysis of recent case law shows a growing body of decisions by appellate courts identifying a number of extricable errors of law inconsistent with the general deferential standards established in Sattva. An approach to the standard of review informed by a focus on cognitive judicial tasks, would better serve the goals of judicial efficiency and legal consistency underlying the distinction between questions of fact and question of law.

\section{The Evolution of the Jurisprudential Framework}

This section briefly summarizes the development of Canadian case law regarding 1) whether contractual interpretation is a question of law, fact, or mixed fact and law, and 2) the appropriate standard of appellate review of decisions interpreting a contract. Rather than providing a comprehensive historical account, the discussion is limited to tracing the development of the two conceptual underpinnings of current case law: contextualism in contractual interpretation and deferentialism in appellate review. ${ }^{24}$

\section{A PRE-SATTVA: CONTEXTUALISM VERSUS DEFERENTIALISM}

\section{From text to context}

Traditionally, Canadian courts have regarded the interpretation of contract as a question of law, reviewable by an appellate court on a standard of correctness. ${ }^{25}$ Over the past two decades, this principle has become increasingly at odds with the contextualist approach to contractual interpretation that Canada has progressively adopted. Under this approach, the judge should ascertain the meaning of the contract text by taking into account the circumstances surrounding its formation (the factual matrix) even without a prior finding of ambiguity. ${ }^{26}$ As courts adopted the contextualist approach to interpretation, they began to question the traditional qualification of contractual interpretation as a question of law, stating contractual interpretation often involves questions of mixed fact and law. More significantly, several appellate courts portrayed this qualification as mandated by the central relevance of the factual matrix in contractual interpretation.

\footnotetext{
${ }^{23}$ See supra note 17.

${ }^{24}$ For an excellent examination of the pre-Sattva case law, see Hall supra note 19.

${ }^{25}$ See e.g., Gerald F Dykeman Ltd v Schmidt, [1992] NBJ No 561, 1992 Carswell NB 438 (CA) and Palumbo v Research Capital Corp (2005), 72 OR (3d) 241, [2004] OJ No. 3633/

${ }^{26}$ See e.g., MacMillan Bloedel Ltd v British Columbia Hydro \& Power Authority, (1992), 19 B.C.A.C. 215 (CA); 1992 CanLII 2287 (BC CA) at para 30; Moore Realty Inc v Manitoba Motor League, 2003 MBCA 71, 173 Man R (2d) 300 at para 18; Dumibrell v Regional Group of Companies Inc 2007 ONCA 59 at para 47, (2007), 85 OR (3d) 616 at para 47.
} 


\section{Deferentialism}

The qualification of the nature of contractual interpretation is related to the standard of appellate review. The Supreme of Court of Canada outlined the law of appellate standards of review in Housen. In this landmark decision, the Court adopted a deferential conception of appellate review, ${ }^{27}$ according to which the appeal court's intervention is limited to "pure" or "extricable" questions of law. Housen establishes the following categorizations: questions of law are reviewed on a standard of correctness; questions of fact and inferences of fact are reviewed on a standard of palpable and overriding error; and questions of mixed fact and law are reviewed on a standard of palpable and overriding error "unless it is clear that the trial judge made some extricable error in principle with respect to the characterization of the standard or its application, in which case the error may amount to an error of law."28

Three aspects of this approach to appellate review are worth emphasizing. First, In Housen, the Court accorded the same degree of deference to inferences of fact as findings of fact. Justice Bastarache, writing for the dissenting judges, criticized this decision, maintaining that an appeal court must be free to overturn an inference of fact not only if there is a palpable and overriding error in the factual findings upon which the inference is based, but also if the drawing-inference process is itself unreasonable. ${ }^{29}$ In reviewing an inference of fact an appellate court should not be limited to errors of logic, but must verify whether the inference can reasonably be supported by the trial judge's findings of fact.

The Court characterized mixed questions as legal inferences and accorded them a similar degree of deference as inferences of fact. Because both mixed questions and factual inferences involve drawing inferences from the underlying facts, "[T] policy reasons which support a deferential stance to the trial judge's inferences of fact, also, to a certain extent, support showing deference to the trial judge's inferences of mixed fact and law." ${ }^{31}$ At the same time, the Court emphasized that the standard of review for questions of mixed fact and law is initially indeterminate. Where the question is found to be one of mixed fact and law, the determination of the standard of review does not follow directly from this categorization, but requires the appellate court to take a further step and locate the question at precisely the proper point on the fact-law spectrum. ${ }^{32}$ The court must determine whether the matter is more of a legal principle (and sits toward the error of law end of the spectrum) or is one in which legal principle and facts are inextricably intertwined. When fact and law are inextricably intertwined it is not possible to place a question at a precise point on the spectrum, and the deferential standard applies. ${ }^{33}$

\footnotetext{
${ }^{27}$ Daniel Jurtas, “The Narrowing Scope of Appellate Review: Has the Pendulum Swung Too Far?” 200632 Man LJ 61 at 68 .

${ }^{28}$ Housen, supra note 17 at para 37.

${ }^{29}$ Ibid at para 104 and 150 .

${ }^{30}$ Ibid at para 26. The Court emphasizes the difference lies in whether the inference drawn from the fact is legal (mixed questions) or factual (inferences of fact).

${ }^{31}$ Ibid at para 32.

${ }^{32}$ Ibid at para 27.

${ }^{33}$ Housen provides a useful clarification on this point, which is often referred to in subsequent appellate courts' decisions: "Matters of mixed fact and law lie along a spectrum. Where, for instance, an error with respect to a finding
} 
The distinction between a mixed fact and law question and an extricable error of law hinges on the degree of generality of the question being considered. This conclusion stems from the analysis of the different roles of trial courts and appellate courts. The primary role of trial courts is "to resolve individual disputes based on the facts before them and settled law." ${ }^{34}$ Thus, a general question that may qualify as a principle of law, or one expected to be of interest to judges and lawyers in the future, is more likely to be a question of law reviewable for correctness. ${ }^{35}$ Meanwhile, the primary role of appellate courts is "to delineate and refine legal rules and ensure their universal application." 36 Therefore, where "the matrices of facts at issue ... are so particular, indeed so unique" that the decision would not have precedential value, it is a question of mixed law and fact generally subject to a more stringent standard of review, unless the error is traceable to an error in principle that would engage the lawmaking function of an appellate court. ${ }^{37}$

\section{Diverging views among appellate courts}

Since Housen the nature of contractual interpretation has been the subject of considerable debate in Canadian case law. ${ }^{38}$ Prior to Sattva, two alternative approaches emerged in the jurisprudence of appellate courts, exemplified by two decisions of the Ontario Court of Appeal: MacDougall v MacDougall ${ }^{39}$ and Plan Group v Bell Canada. ${ }^{40}$

The dispute in MacDougall arouse from litigants' divergent interpretations of the spousal support section of a marriage contract. The appellant argued the contract raised a question of law to be reviewed on correctness. The respondent argued the question was one of mixed fact and law, requiring a standard of review of palpable and overriding error. The Ontario Court of Appeal stated that questions of law, questions of fact, and questions of mixed fact and law are involved in the process of contractual interpretation. ${ }^{41}$ The judge must first classify the question by looking at the judicial task involved in the question at issue and then position it along the fact-law spectrum.

The Court identified three judicial tasks involved in contractual interpretation. First, the trial judge must apply the proper principles of contractual interpretation. ${ }^{42}$ A failure to correctly identify and follow these principles is an error of law attracting review on a standard of correctness. ${ }^{43}$ Second, the trial judge's determination of the factual matrix,

of negligence can be attributed to the application of an incorrect standard, a failure to consider a required element of a legal test, or similar error in principle, such an error can be characterized as an error of law, subject to a standard of correctness. Appellate courts must be cautious, however, in finding that a trial judge erred in law in his or her determination of negligence, as it is often difficult to extricate the legal questions from the factual. It is for this reason that these matters are referred to as questions of 'mixed law and fact.' Where the legal principle is not readily extricable, then the matter is one of 'mixed law and fact' and is subject to a more stringent standard" (para 36).

${ }^{34}$ Housen, supra note 17 at 9.

35 Ibid at para 28 (citing Southam, supra note 20 at para 37)

${ }^{36}$ Ibid at para 9.

${ }^{37}$ Ibid at para 28, 36-37; Southam, supra note 20, at para 37.

${ }^{38}$ Hall, supra note 19; Swan, supra note 7 at $736 \mathrm{n} 246$.

39 (2005), 262 D.L.R. (4th) 120, [20051 O.J. No. 5171 (C.A.). [MacDougall]

402009 ONCA 548, 96 OR (3d) 81 [Bell]. For further discussion of MacDougall and Bell, see Hall, supra note 19 at 440-451.

${ }^{41}$ MacDougall, supra note 39 at para 30-33.

${ }^{42}$ Ibid.

${ }^{43}$ Ibid. 
consideration of extrinsic evidence, and assessment of the evidence as a whole is a question of fact not to be overturned except in the case of palpable or overriding error. ${ }^{44}$ Third, the judge applies legal principles to the language of the contract using relevant facts and inferences. This is a question of mixed fact and law that should not be overturned absent a palpable and overriding error, unless an extricable error of law is identified. ${ }^{45}$ The Court stated the contextualist approach to contractual interpretation requires the trial judge to engage in the consideration of extrinsic evidence and that Housen provided a deferential standard of review with respect to the trial judge's consideration of evidence. $^{46}$

In Bell Canada v The Plan Group, the Ontario Court of Appeal held that contractual interpretation is a question of law reviewed on a standard of correctness. Blair J.A., writing for the majority, challenged the categorical statement, "[Q]uestions of mixed fact and law always attract the palpable and overriding error standard. . . . To say that a matter raises a question of mixed fact and law, by itself, does not mean that the standard of appellate review is necessarily one of palpable and overriding error." ${ }^{\prime 47}$ The majority emphasized the intrinsically legal nature of interpreting a contract. Housen tackled the issue of the appropriate standard of review for a negligence action and therefore did not directly address the appropriate standard for contractual interpretation. ${ }^{48}$ While negligence is a matter "in which the legal principle and the facts are inextricably intertwined" that "falls more toward the factual end of the spectrum," contractual interpretation is "a matter of legal principle and sits toward the error of law end of the spectrum." ${ }^{, 49}$ It is a legal exercise, "calling upon the learning and training that judges and lawyers acquire over years of experience."

In Bell, the Court evaluates the extent to which legal rules in contractual interpretation are separated from the factual matrix. Blair J.A. recognizes there may be questions involving the determination of the factual matrix that evoke fact-finding functions, and that those decisions are to be reviewed on a deferential standard. But, apart from the truly factual aspects that may underlie the task, the exercise of interpreting a contract "is not essentially a fact-finding exercise," and trial judges "have no particular advantage over appellate judges in the art of contractual interpretation. ${ }^{51}$ Based on these premises, and as "[t]here were no underlying evidentiary or factual issues of a contested nature that the application judge was required to resolve," the majority concludes the issue raised on that particular appeal was a question of law reviewable on a standard of correctness. ${ }^{52}$

\footnotetext{
${ }^{44}$ Ibid at para 31.

45 Ibid at para 32 (quoting Housen at para 36).

${ }^{46}$ Ibid at para 33.

${ }^{47}$ Ibid at para 26 (emphasis added).

${ }^{48}$ Ibid at para 25 (quoting MacDougall, supra note 39 at para 25).

${ }^{49}$ Ibid at para 27. Similarly, "Whereas the application of legal principles to the facts in a negligence action is very much a fact-driven exercise, the interpretation of a contract-leaving aside the factual issues that may underlie the task-is not; it is very much a legal exercise" (para 25).

${ }^{50}$ Ibid at para 30.

${ }^{51}$ Ibid.

${ }^{52}$ Ibid at para 33.
} 


\section{B SATTVA AND ITS PROGENY: CONTEXTUALISM INVOLVES DEFERENTIALISM}

Before Sattva, the law concerning the nature of contractual interpretation and the appropriate standard of appellate review of a decision interpreting a contract was unsettled; a clarification from the Supreme Court was long overdue. ${ }^{53}$ Sattva, as discussed below, attempts to settle the issue, yet instead raises more questions than it answers.

\section{Sattva: Contract interpretation is generally a question of mixed fact and law}

At issue in Sattva was whether the British Columbia Court of Appeal should have granted leave to appeal a commercial arbitration award. Under the British Columbia Arbitration Act 1996, leave to appeal could only be granted on a "point of law." This raised the issue of whether the arbitrators' interpretation of the contract involved a question of law or a question of mixed fact and law. The Supreme Court found no question of law had been involved and that the BC courts had erred in granting leave to appeal the arbitral award. The Court held that contractual interpretation generally involves issues of mixed fact and law subject to deferential review on appeal, unless a question of law can be extricated from the interpretation process. ${ }^{55}$

To support this conclusion, the Court constructs three arguments to provide a logical connection between contextualism in contractual interpretation and deferentialism in appellate review. First, the Court contends that under the contextualist approach, contract interpretation is essentially a fact-specific exercise. The meaning of words is derived from a number of contextual factual elements, including the background, the commercial purpose of the agreement, the knowledge of the genesis of the transaction, and the market in which the parties are operating. ${ }^{56}$ Inferring the meaning of contractual words from the context is therefore a fact-specific inquiry best left to the trier of fact. Second, and relatedly, contractual interpretation does not fit well with Housen's definition of a question of law as a question "about what the correct legal test is." 57 Judges apply principles of contractual interpretation to the words of the written contract, considered in light of the factual matrix. ${ }^{58}$ This appears closer to a question of mixed fact and law, defined in Housen as "applying a legal standard to a set of facts." interpretation issues have a low degree of generality and therefore a low precedential value. Because "legal obligations arising from a contract are, in most cases, limited to the

\footnotetext{
${ }^{53}$ Hall, supra note 19 at 452.

${ }^{54} \mathrm{~S} 31.1$

${ }^{55}$ In the aftermath of Sattva, a few appellate judges have pointed to its unique factual circumstances (an appeal from an arbitral decision in the context of a statute limiting appeals to questions of law alone) as a basis for limiting its precedential value; see e.g., Vallieres v Vozniak, 2014 ABCA 290, [2014] AJ No. 964, [Vallieres], at para 12. However, in Heritage Capital Corp v Equitable Trust Co., 2016 SCC 19; [2016] 1 S.C.R. 306 the Supreme Court extended the reasoning in Sattva to the appellate review of judicial decisions. Heritage confirms Sattva's deferential rule applies both to arbitration decisions and trial court decisions. See also Cherniak, supra note 10 at 7.

${ }^{56}$ Sattva, supra note 1 at para 47 (quoting Reardon Smith Line at 574, per Lord Wilberforce)

${ }^{57}$ Ibid at para 49.

${ }_{58}^{58}$ Ibid at para 50.

${ }^{59} \mathrm{Ibid}$ at para 49 (quoting Housen, supra note 17 para 26 and referencing Southam, supra note 17 at para 35).
} 
interest of the particular parties, $" 60$ contractual interpretation questions should be qualified as a question of mixed fact and law, and intervention by courts of appeal should be limited to "cases where the results can be expected to have an impact beyond the parties to the particular dispute." 61 Justice Rothstein recognizes it is possible to identify extricable questions of law from what is initially characterized as a question of mixed fact and law. ${ }^{62}$ However, he emphasizes, "[T] he circumstances in which a question of law can be extricated from the interpretation process will be rare." ${ }^{.63}$ In the Court's view, the close relationship between the application of principles of contractual interpretation and construction ultimately given to the instrument means that "extricable" questions of law are extremely unlikely to occur in contractual interpretation. ${ }^{64}$ Yet Sattva did not involve a dispute about the admissibility of extrinsic evidence. Therefore, as Waddams observed, Sattva "extends the original concept of deference where there are actual findings of fact and where a trial judge has had the advantage of hearing a seeing witnesses, to cases where there may be no witnesses and no findings of fact in the ordinary sense of the phrase." 65

\section{Ledcor: The exception of standard form contracts}

Immediately after Sattva was handed down, dissent emerged among provincial appellate courts on which standard of appellate review should apply to standard form contracts. Many appellate courts distinguished Sattva with respect to standard form contracts, ${ }^{66}$ while others applied Sattva and deferred to trial courts' interpretations. ${ }^{67}$ This disagreement culminated in Ledcor, in which the Supreme Court established that the interpretation of a standard form contract is better characterized as a question of law subject to correctness review. ${ }^{68}$

The Court explains the interpretation of standard form contracts should be recognized as an exception to the holding in Sattva because the reasons underlying the qualification of contractual interpretation as a mixed question are less compelling when standard form contracts are involved. For example, the factual matrix is generally less relevant to standard form contracts because the parties do not negotiate terms; terms are offered to the receiving party on a take it or leave it basis. ${ }^{69}$ The interpretation of standard form contracts also may have significant precedential value. A standard form agreement may be the same for all customers of a single company, or a form may be commonly used

\footnotetext{
${ }^{60}$ Ibid at para 52.

${ }^{61}$ Ibid at para 51.

${ }^{62}$ See Sattva, supra note 1.

${ }^{63}$ Ibid at para 55.

${ }^{64}$ Ibid.

${ }^{65}$ Waddams, supra note 19 at 50.

${ }^{66}$ See e.g., Vallieres, supra note 54 (applying the correctness standard to a standard form real estate contract); MacDonald v Chicago Title Insurance Co. of Canada, 2015 ONCA 842, 127 OR (3d) 663 at para 41 (holding that the correctness standard of review applies to decisions interpreting standard form insurance contracts); Monk v Farmer's Mutual Insurance Company, 2015 ONCA 911, 128 OR (3d) 710; Daverne v John Switzer Fuels Ltd, 2015 ONCA 919, 128 OR (3d) 188.

${ }^{67}$ Metrolinx v Enbridge Gas Distribution Inc, 2015 ONCA 429, [2015] OJ No 3129 at para 35-36.

${ }^{68}$ Ledcor, supra note 2 at para 24.

${ }^{69}$ Ibid at para 27-29. The Court maintains when the factual matrix is relevant in standard form contracts it tends not be specific to the particular parties; rather, it is usually "the same for everyone who may be a party to a particular standard form contract" (para 31).
} 
throughout an industry. ${ }^{70}$ The uniformity of the factual matrix across many contracting parties suggests the interpretation of a standard form contract "may be applied in future cases involving identical or similar worded provisions," and therefore be of interest to judges and lawyers in the future. ${ }^{71}$

\section{Teal: The "extricable" error of law}

Teal provides further guidance on the distinction between questions of law and questions of mixed fact and law in contractual interpretation and clarifies the notion of an extricable question of law. The appeal arose from Teal's claim for compensation under the British Columbia Forestry Revitalization Act. Teal and British Columbia entered into negotiations conducted under a settlement framework agreement which provided that no interest would be payable under any compensation British Columbia would provide. Teal and the province disagreed on the proper valuation method to be used to determine compensation and the negotiations failed. The dispute went to arbitration and to the Court of Appeal.

At issue before the Supreme Court was whether the arbitrators' decision on the contractual interpretation issue involved a question of law or a question of mixed fact and law. The Court ruled the question of which valuation method should be used to value Teal's improvements was a question of mixed fact and law whose determination was "inextricably linked to the evidentiary record at the arbitration hearing, where various experts opined on the virtues of conflicting valuation methodologies." 72 Therefore, the courts had no jurisdiction to review the contractual interpretation issue, as the arbitrator was best situated to weigh the factual matrix when interpreting the parties' agreement.

The majority confirmed Sattva's holding that generally contractual interpretation involves questions of mixed fact and law, as it requires applying principles of contractual interpretation to contractual facts. ${ }^{73}$ At the same time, Justice Gascon, writing for the majority, explicitly recognized contractual interpretation may involve factual, legal, and mixed fact and law questions and that the characterization of contractual interpretation issues before a court "requires delicate consideration of the narrow issue actually in dispute." "74 In addition, the majority emphasized that extricable questions of law are better understood not as a fourth and distinct category of questions (alongside questions of law, fact, mixed fact and law), but "as a covert form of legal question-where a judge's (or arbitrator's) legal test is implicit to their application of the test rather than explicit in their description of the test." $" 75$ The Court noted that counsel often strategically frame a mixed question as a legal question to gain jurisdiction in appeals from arbitration awards or a favourable standard of review in appeals from civil litigation judgments. However, the identification of an alleged legal error should be based only on the arbitrator's application of the wrong test, not on the fact that one would have applied the appropriate legal test differently. Therefore, the majority admonished, courts must be vigilant in distinguishing

${ }^{70}$ Ibid at para 39.

${ }^{71} \mathrm{Ibid}$ at para 43.

${ }^{72}$ Teal, supra note 3 at para 51.

${ }^{73}$ Ibid at para. 47.

${ }_{75}^{74}$ Ibid at para 47.

${ }^{75}$ Ibid at para 44. 
between "a party alleging that a legal test may have been altered in the course of its application (an extricable question of law)" and "a party alleging that a legal test, which was unaltered, should have, when applied, resulted in a different outcome (a mixed question)." ${ }^{, 76}$ In short, it is one thing to apply the wrong legal test, and another to apply the right legal test wrongly.

\section{CONCEPTUAL BUILDING-BLOCKS}

A cursory overview of the Canadian case law on the nature of contractual interpretation and appropriate standard of review will help identify the conceptual premises underpinning Sattva and its progeny. The proposition that contractual interpretation generally involves questions of mixed fact and law reviewable on appeal on a deferential standard rests on four conceptual premises:

1. The degree of generality, conceived as determinative of the precedential value, is the key difference between a question of law and a question of mixed fact and law.

2. Questions of mixed fact and law generally attract a deferential standard of appellate review.

3. Issues of law application generally involve questions of mixed fact and law.

4. Under the contextual approach, contractual interpretation issues are closer to questions of mixed and law.

Premises 1-3 - which pertain to the general distinction between fact and law-are examined in Section III. Premise 4-which relates more specifically to the distinction between fact and law in the area of contractual interpretation-is discussed in Section IV.

\section{Questions of Fact and Questions of Law}

This section argues the distinction between questions of fact and questions of law should be based on careful consideration of 1) the cognitive task performed by the judge in adjudicating the issue, and 2) the relative institutional advantages of trial judges versus appellate courts in performing this task. Drawing on the philosophical analytical theory of judicial reasoning, the analysis identifies the different types of inferential reasoning judges use to justify their judgments of fact and their application of the law to these facts. Based on this analysis, a classificatory framework of questions is proposed.

\section{A METHODOLOGY}

Much of the confusion surrounding the distinction between questions of fact and questions of law arises from mistakenly reading an ontological distinction into a policy one. ${ }^{77}$ The distinction between question of law and question of fact is a tool for

\footnotetext{
${ }^{76}$ Ibid at para 45

77 The distinction between "questions of fact" and "questions of law" cannot rest on the ontological status of "fact" and "law." There is no a priori objective definition of facts independent of legal relevance; rather, the law defines the facts that are the object of judicial fact-finding by determining what "facts" constitute the object of "questions of fact." "Facts" are transformed into "facts in law" exclusively by referencing the context within which they acquire legal significance. See Hans Kelsen, General Theory of Law and State (Cambridge: Harvard University Press, 1945) at 135-
} 
distributing the institutional competence between trial judges and appellate courts to achieve judicial efficiency and legal consistency. ${ }^{78}$ This allocative use of the distinction must be separated from the theoretical/ontological question of what is fact and what is law. ${ }^{79}$ The relevant question is not what one would classify as a question of fact or question of law based on the ontological status of factual and legal issues, but what should be treated by the law as a question of fact or question of law in order to best pursue the goals of judicial efficiency and legal consistency. ${ }^{80}$ In this sense, it is the allocative criteria that inform the distinction, not the distinction that informs the allocative criteria. ${ }^{81}$

The preceding consideration suggests the labels "questions of fact" and "questions of law" should be attached to the question being considered based on a comparative assessment of the relative advantages of trial judges versus appellate courts in achieving these two goals. The challenge is identifying the specific dimension against which the relative competence of trial judges versus appellate courts must be assessed. What makes an issue better decided by a trial judge rather than a court of appeal, or vice versa? It is suggested here that the comparative assessment should focus on the differential ability of the various adjudicating bodies to perform the cognitive task the judge must accomplish to adjudicate the specific issue under consideration. ${ }^{82}$ Based on this premise, a useful methodology for categorizing questions along the fact-law spectrum and determining the appropriate standard of review is to undertake two analytical steps: 1) identify the type of cognitive task involved in solving a particular issue, and 2) assess the relative competence of the various actors involved in the adjudication process in accomplishing that particular task.

The theory of judicial reasoning suggests the type of inferential reasoning involved in adjudicating a given issue is largely a function of the logic-semantic features of the

136; Silving, supra note 14 at 644; Jackson, supra note 16 at 87; Nerhot, supra note 16 at 56; Varga, supra note 16 at 61); Mazzarese, supra note 16 at 300; Christie, supra note 16 at 41.

At the conceptual level, a "hermeneutic circle" or "spiral" is involved in the application of law. Not only does the law determine the relevant facts, but the relevant law is identified in light of the facts. See Giuseppe Zaccaria, L'Arte dell'interpretazione. Saggi sull'Ermeneutica Giuridica Contemporanea (On the Art of Interpretation. Essays on Contemporary Legal Hermeneutics) (Padua: Cedam, 1990). See also HL Ho, A Philosophy of Evidence (Oxford: Oxford University Press, 2008) at 7 ("Facts and law are considered in tandem and adjusted to one another continuously until a result is reached").

Finally, legally relevant facts may include features not empirically observable or whose definition involves a theoretical (that is, non-empirical) element. For example, in deciding questions of fact the judge may have to formulate propositions concerning facts "evaluatively determined," "assessment of probability" or "counterfactual conditionals." Yet the judge can only decide on questions of fact in light of the purpose and axiological assumptions of the relevant law. This is discussed in greater detail below.

${ }^{78}$ See e.g., Thayer, supra note 16 at 161; Leon Green, Judge and Jury (Kansas City: Vernon Law Book, 1930) at 278279; MacCormik, supra note 15 at 95; Monaghan, supra note 16 at 234; Yalnazov, supra note 16. However, Endicott casts doubt on the assumption that the fact/law distinction can be conceptualized in light of its allocative function. Supra note 16 at 292.

${ }^{79}$ See supra note 77. See also,Monaghan, supra note 16 at 234-235; Christie, supra note 16 at 39; H Hart \& A Sacks, The Legal Process: Basic Problems in the Making and Application of Law (Westbury, N.Y.: Foundation Press, 1958) at 376.

${ }^{80}$ See Jackson, supra note 16 at $86-87$.

${ }^{81} \mathrm{Ibid}$. See also Monaghan, supra note 16 at 237.

${ }^{82}$ Christie, supra note 16 at 39. See also Whitford, supra note 19 at 933. 
propositions to which the cognitive activity of the judge is directed ${ }^{83}$ From this analytical standpoint, the activity of the judge is conceptualized as a cognitive exercise focusing on assessing the reliability of statements and propositions proffered by the parties or formulated by the judge herself. ${ }^{84}$ The fact-finding, for example, assesses the truth or falsehood of statements concerning facts relevant to the parties' claim. Similarly, the law finding determines the applicable rule of law and establishes semantic relationships between the predicates used by the relevant legal language.

In addition, it is useful to note the semantic features of the propositions used in the adjudicatory context are, at least to some extent, a function of the theoretical assumptions underlying the applicable legal rules and principles. For example, the expression "contractual intent" bears different semantic significance depending on whether a subjective or objective theory of contractual interpretation is adopted. Under the subjective theory-historically originated in civil law jurisdictions-the expression denotes an empirical element, while under the objectivist framework-traditionally prevailing in common law jurisdictions-the expression acquires a stronger normative dimension. ${ }^{85}$ Therefore, the type of inferential reasoning used by the judge to assess the reliability of sentences pertaining to contractual intent changes depending on the theoretical assumption embedded in the relevant legal framework. There is a significant difference between assessing the truth behind an existential statement concerning the empirical intent of the parties (objective framework) and constructing the parties' intent based on a normative assessment of what meaning a reasonable person would ascribe to the contract's text (subjective framework). This crucial point will be discussed later in greater detail.

The next step of the discussion is to identify the different judicial tasks involved in the adjudication process.

\section{B FACT-FINDING}

The tripartite categorization of questions underpinning the current structure of appellate review parallels the three-step process of judicial reasoning, whereby the judge first establishes the historical facts, then determines the applicable law, and finally applies the relevant law to the facts as found. Each step involves questions of fact, questions of law, and questions of mixed fact and law, respectively. This categorization implicitly relies on the troubling assumption that fact and law constitute two ontologically distinct and separate entities. ${ }^{86}$ This article offers a more nuanced categorization, focusing on the judicial cognitive tasks involved in the various adjudicative steps.

\section{The object of fact-finding}

Scrutinizing the cognitive task requires a precise examination of the relationship between the fact and its legal qualification. Legal analytical philosophy has long illuminated this

\footnotetext{
${ }^{83}$ Wróblewski, supra note 16 at $161-164$.

${ }^{84}$ Wróblewski, supra note 15 at 133.

${ }^{85}$ For a very useful historical reconstruction of the objective theory of contract interpretation, see Joseph M Perillo, "The Origins of the Objective Theory of Contract Formation and Interpretation" (2000) 69 Fordham L Rev 427.

${ }^{86}$ The separation between fact and law is untenable on ontological grounds; see supra note 77 .
} 
point. ${ }^{87}$ Legal rules take the form of conditionals, which are divided into two components: antecedent and consequent. ${ }^{88}$ The antecedent defines the conditions that trigger the application of the rule. ${ }^{89}$ It is also called the factual predicate, ${ }^{90}$ as it contains the description of the factual scenario whose occurrence is a necessary and sufficient condition for the applicability of the rule. The consequent prescribes the legal consequences that follow when the conditions specified in the antecedent (or factual predicate) occur. Schauer provides an example of the following rule: "If a person drives in excess of 55 miles per hour, then that person must pay a fine of fifty dollars." 91 The antecedent (or factual predicate) is the expression "If a person drives in excess of 55 miles per hour", while the consequent is the expression "then that person shall pay a fiftydollar fine". Importantly, in describing the factual predicate, the legal language makes use of predicates - that is, terms that designate classes of objects (persons, actions, and state of affairs) by means of generalizations. In the example, the factual predicate contains the predicates "person", "drive", and "in excess of 55 miles per hour".

When adjudicating a dispute, the judge must establish a logic-semiotic correlation between the factual predicate $F$ (as described in the prima facie applicable rule) and the particular facts of the case $f$ (the historical fact that existed at time $t$ and place $p$ ). In so doing, the judge must first determine the veracity of the statement concerning the existence of $f$. This existential statement $t^{92}$ takes the form "fact $f$ exists at $t$ and in $p$." Then, the judge must determine whether $f$ is contained within the scope of the factual predicate $F$. In our example, assume that a person - call her Jane - has been driving in excess of 55 miles per hour at a particular place and time, and the judge must establish whether the rule $\mathrm{R}$ applies. The judge must first ascertain the veracity of the statement "Jane was driving the car in excess of 55 miles per hour at time $t$ and place $p$ ". Then, she must determine whether this fact is contained within the factual predicate of rule $\mathrm{R}$ - "a person driving in excess of 55 miles per hour".

These considerations help identify four distinct cognitive tasks involved in the judicial application of law:

1. Identify a prima facie applicable legal rule $R$.

2. Determine the truth or falseness of the existential statement " $f$ exists at $t$ and in $p . "$

3. Determine the scope of the factual predicate $F$.

4. Determine whether $f$ is contained in $F$.

\footnotetext{
${ }^{87}$ See e.g., Frederick F Schauer, Playing by the Rules: A Philosophical Examination of Rule-Based Decision-Making in Law and in Life (Oxford: Oxford University Press, 1991); Wróblewski, supra note 15. The distinction between interpretation of statutes and interpretation of precedent is not examined here, as it is not decisive for the purposes of the fact-law distinction.

${ }^{88}$ I provide here a simplified illustration of the structure of the legal norms and judicial tasks involved in adjudication based on the conceptual model developed by Wróblewski, supra note 15 at 132-137 and 190-192.

${ }^{89}$ Schauer, supra note 87 at 23.

${ }^{90}$ Ibid. at 23.

${ }^{91}$ Ibid

${ }^{92}$ Wróblewski, supra note 16 at 162.
} 
Task (2) defines the object of the judicial ascertainment of fact, which is discussed in this subsection; Tasks (1), (3), and (4) define the object of the judgment of law discussed in the following subsection. ${ }^{93}$

\section{Facts descriptively determined and facts evaluatively determined}

Much of the confusion surrounding the categorization of questions stems from the failure to appreciate that the cognitive task underlying the judicial ascertainment of facts changes depending on how the facts are described by the legal language. Wróblewski, who first examined this point, emphasized the importance of distinguishing between facts determined descriptively and facts determined evaluatively. The importance of this distinction is reflected in the process of verification of the existential statements. ${ }^{94}$

When facts are determined descriptively, the existential statement takes the form identified above, " $f$ exists at $t$ and in $p$." This statement is a descriptive proposition that can be either true or false. In our previous example, the existential statement "Jane was driving the car at time $t$ and place $p$ " was descriptive. The logic employed by the judge to ascertain the truth of this type of existential statement is the logic of empirical inferences based on factual evidence. That is, descriptive statements result from a chain of statements of evidence concerning empirical facts. Statements of evidence are linked by directives of proof which are rules of inferential reasoning dictated by the logic of empirical evidence and legal rules governing the admission of evidence. ${ }^{95}$

By way of contrast, when facts are determined evaluatively, the existential statement takes the form " $f$ exists at $t$ and in $p$ and has the value $V . " 96$ This is a compound statement that combines a descriptive proposition ( $f$ exists at $t$ and in $p$ ) with an evaluative judgment ( $f$ has the value $V$ ). For example, assume that the rule $\mathrm{R}$ takes the form "If a person drives at an unreasonable speed, then that person must pay a fine of fifty dollars." In this case, the existential statement that must be proven true for rule $\mathrm{R}$ to apply takes the following form: "Jane was driving the car at time $t$ and place $p$ at an unreasonable speed". This combines a descriptive proposition, "Jane was driving the car at time $t$ and place $p$ ", with an evaluative judgment, "the speed Jane was driving was unreasonable".

Crucially, the descriptive proposition and the evaluative judgment rest on two different forms of rationality. The descriptive proposition, as noted above, can be either true or false and is derived from empirical inferences based on factual evidence. The evaluative judgment requires two further steps. ${ }^{97}$ First, the judge chooses the axiological criteria

\footnotetext{
${ }^{93}$ One crucial theoretical impasse in characterizing the nature of questions comes from a failure to properly appreciate the hermeneutic-legal connection between steps (1) and (2). The description of the relevant facts $F$ provided by the relevant legal language determines the state of affairs that comprise the $f$ to be proved. That is, the fact to be proved is determined on the basis of the fact as referred to in the legal language. This aspect of the fact-law relationship is the source of much of the complexity associated with the distinction between questions of fact and questions of law.

${ }^{94}$ Wróblewski, supra note 16 at 164 . A comprehensive analysis of the many ways facts are referred to by the law is out of the scope of this paper. For a more comprehensive discussion, see Wróblewski, supra note 13 at 138-141 and supra note 16, and Michele Taruffo, La Prova dei Fatti Giuridici, (The Judicial Ascertainment of Facts) (Milan: Giuffre, 1992) at 91-142.

${ }^{95}$ The terms "statement of evidence" and "directives of proof" are borrowed from Wróblewski, supra note 15 at 163.

${ }^{96}$ Examples of facts evaluatively determined are "moral harm", "good faith", and "reasonable expectations".

${ }^{97}$ See Taruffo, supra note 16 at 48.
} 
against which the facts must be assessed. In our example, the judge must determine the criteria defining the notion of "reasonable speed". Second, based on the selected axiological criteria, a general evaluative statement of the form, " $F$ has the value $V$ " is formulated. For example, the judge may state that "driving in excess of 55 miles per hour is an unreasonable speed." This statement provides the logical premise for the value judgment about the individual fact $f$. That is, based on the value premise provided by the general evaluative statement, the judge qualifies the particular fact at hand. ${ }^{98}$ In the example, the judge will conclude that since driving in excess of 55 miles per hour is an unreasonable speed, and since Jane was driving in excess of 55 miles per hour, then Jane was driving at an unreasonable speed.

This analysis illuminates an essential aspect of the distinction between questions of fact and questions of law. Judicial evidence can only be used to confirm statements of fact determined descriptively. As Taruffo observes, "[O]nly facts descriptively determined can be 'proved' in the proper sense, since they are the only facts knowable on the basis of empirical evidence." 99 By contrast, value judgments involved in the evaluatively determined facts can be rationally justified but cannot be proved. It follows that the compound existential statement of a fact evaluatively determined could be either true/false, based on the truth or falsehood of the descriptive propositions referring to the empirical facts, or valid/invalid, depending on the logical strength of the argumentative reasoning used in the value judgment. ${ }^{100}$ In the example above, the compound statement "Jane was driving the car at time $t$ and place $p$ at an unreasonable speed" may be true/false based on the truth or falsehood of its descriptive component "Jane was driving the car at time $t$ and place $p$ ", or valid/invalid depending on the strength of the argumentative reasoning supporting the evaluative judgment that "the speed Jane was driving was unreasonable". This partially explains why descriptive statements of empirical fact should be regarded as questions of fact, while statements of normatively determined fact may comprise both questions of fact and questions of law. This point will be discussed later in greater detail.

\section{Proof by circumstantial evidence: Evaluation in inference drawing}

The preceding discussion implicitly refers to primary facts, or facts directly proved by oral testimony or documentary evidence. However, the judge often has no direct knowledge of the primary facts and instead establishes them by means of circumstantial evidence. She deduces the existence or inexistence of facts to be proved (factum probandum) through inferences drawn from established secondary facts. This aspect of judicial reasoning is a crucial element of this paper, as contractual interpretation requires the judge to draw inferences from the factual circumstances surrounding the formation of the contract. Much of the confusion surrounding the distinction between questions of fact and questions of law is related to the characterization of these inferences as either factual or legal.

\footnotetext{
98 Ibid.

${ }^{99}$ Ibid at $50-51$.

${ }^{100}$ Ibid.
} 
An inference can be legal in nature despite it producing a conclusion of fact. To understand this, the inference-drawing process should be considered in light of the descriptive or evaluative nature of the premises of the judicial inference. ${ }^{101}$ If the inference the judge draws from the proven facts is based on concepts that have a descriptive meaning and are expressed by descriptive statements (i.e., scientific laws or common experience), the inference is factual; the next task is to determine its degree of conclusiveness. ${ }^{102}$ In other cases, the judge relies on notions of common sense stated in evaluative terms and used as "premises of inferences concerning the judgment of fact."103 In such cases, evaluative judgments occur in the process of establishing facts. ${ }^{104}$ Taruffo provides the following example. Suppose the judge must decide whether the cohabitation of X and Y has become "unbearable." It is common sense that adultery makes spousal cohabitation unbearable, and it is a proven fact that $X$ committed adultery (descriptive statement). To decide whether the cohabitation of $\mathrm{X}$ and $\mathrm{Y}$ has become unbearable, the judge can make the following deductive inference: adultery makes spousal cohabitation unbearable (major premise) and X committed adultery (minor premise); therefore, $\mathrm{X}$ and Y's cohabitation has become "unbearable" (conclusion). If the two premises are accepted, the argument is logically valid. However, while the conclusion of this deductive inference is one of fact, as it concerns the particular fact in issue (the unbearable cohabitation between $\mathrm{X}$ and $\mathrm{Y}$ ), the inference relies on a common-sense belief stated in evaluative terms (adultery makes spousal cohabitation unbearable).

Remarkably, while an inferential step may lead to a conclusion of fact, the inference may be considered legal in nature. That may appear counterintuitive; however, it can be explained as follows. The inference does not rely on a case-specific fact assumption (an assumption about facts specific to a particular controversy); it rather rests upon a social proposition that informs the law and relates to a broad category of social facts. As such, rather than pertaining to fact-finding as defined above, the inference engages the lawmaking function of the court. ${ }^{105}$ In this example, the inference draws on the social proposition that adultery makes spousal cohabitation unbearable.

Finally, issues about the admissibility of evidence must be distinguished from issues about the weighing of evidence. Independent from the legal or factual nature of the inference, the law governing the inference-drawing process mandates the judge admit the relevant evidence, which is weighed according to the applicable standard of proof. This necessarily involves the application of legal principles, yet pertains to fact-finding. From this perspective, as Kerans and Willey observe, "[A]ny question of 'fact' might well engage a question of law automatically and instantly."106

\section{LAW-FINDING}

\footnotetext{
${ }^{101}$ See Taruffo, supra note 16 at 56.

102 Ibid at 52.

${ }^{103}$ Ibid at 53.

104 Ibid

${ }^{105}$ Kerans and Willey, supra note 19 at 153 .

${ }^{106}$ Ibid at 136.
} 
The preceding subsection examined the cognitive tasks involved in judicial fact-finding. It identified the distinction between facts descriptively determined and facts evaluatively determined and emphasized the presence of normative judgments within the inferencedrawing process. This subsection provides a brief account of the cognitive tasks performed by the judge in identifying, formulating, and applying legal rules (that is, "law-finding"). It shows that the conventional distinction between the "interpretation" and "application" of a legal rule - traditionally used to separate questions of facts from questions of mixed fact and law-fails to properly appreciate the similarities and differences across cognitive tasks and therefore ultimately fails to provide coherent guidance toward distinguishing between questions of fact and questions of law. A more nuanced conceptual framework is needed.

Law-finding aims to determine whether the fact of the case $f$ is contained within the scope of the factual predicate $F$ as described in the legal language by the rule $R$. Three sub-tasks can be identified. First, the judge must identify a rule $R$ that is prima facie applicable to the facts of the case $f$. This determination is based on the judge's knowledge of legal rules and principles. Second, the judge identifies the scope of the factual predicate $F$ by ascribing meaning to the relevant linguistic expressions contained in the legal language of rule $R .^{107}$ This interpretive exercise, as clarified later, is conducted by the judge "in abstract"; that is, without specific reference to the particular facts of an issue. Finally, the judge determines whether $f$ falls within the scope of $F$ according to her interpretation of the relevant linguistic expressions used in rule $R$. Consider the previous example of a rule $\mathrm{R}$ prescribing that "If a person drives at an unreasonable speed, then that person must pay a fine of fifty dollars." Assume also that, based on available evidence, the judge has ascertained the fact $f$ that Jane was driving in excess of 55 miles per hour. To determine whether R applies, ${ }^{108}$ the judge must first identify the scope of the factual predicate of the rule R by ascribing meaning to the expression "reasonable speed", and then she must determine whether the particular fact of the case (Jane driving in excess of 55 miles per hour) falls within it. This requires the judge to determine whether driving in excess of 55 miles per hour falls within the scope of the predicate "reasonable speed". The challenge of sorting questions of fact from questions of law often arises from the difficulty in distinguishing and properly characterizing the nature of the latter two steps: ascription of meaning to $F$ and ascription of $F$ to $f$.

This distinction between ascribing meaning to legal linguistic expressions and ascriptions of factual predicates to individual facts is conventionally referred to as the interpretation and application of the relevant legal rule. However, this traditional dichotomy fails to properly characterize the various cognitive tasks involved in adjudicative reasoning and so is not useful for distinguishing between questions of fact and questions of law. ${ }^{109}$ More specifically, one source of confusion is the failure to appreciate the interpretive activity involved in applying the rule to the facts. To emphasize this point, a few legal theorists refer to these steps as interpretation in abstract and interpretation in concrete,

\footnotetext{
${ }^{107}$ For expository convenience, I assume here that the facts have been ascertained. However, to some extent, the interpretation of the meaning of the rule $R$ logically precedes the fact-finding, because the identification of $f$ is determined on the basis of the legal definition of the factual predicate $F$.

${ }^{108}$ It is assumed that $\mathrm{R}$ is the prima facie applicable rule.

${ }^{109}$ See Christie, supra note 16 at 31 and 35.
} 
respectively. ${ }^{110}$ This terminology reflects the interpretive exercise involved both in ascribing meaning to the factual predicate and ascribing the factual predicate to the particular facts in issue.

The distinction between interpretation in abstract and interpretation in concrete parallels the distinction between intension and extension. ${ }^{111}$ Intension is the set of properties or attributes an object must have in order for the predicate to apply. Extension is the set of objects that have the properties described in the predicate. In our example above, the intension of the predicate "reasonable speed", referring to driving conduct, is the attributes driving conduct must possess for it to ascribe the predicate "reasonable speed". Its extension is the class of all possible driving conducts that possess these attributes. Sinclair exemplifies this point by considering the word "green." 112 The intension of the word green is "the criterion according to which the English speaker confidently can ascribe 'green' to objects in an hitherto unobserved factual set-up." 113 The extension is the class of all green things.

The interpretation in abstract is the cognitive exercise whereby the judge solves the intension question (that is, she defines the meaning of the words used in the relevant legal language to determine the attributes required for an individual object to be included in the class of objects designated by the predicate). The interpretation in concrete is the cognitive exercise whereby the judge provides a solution to the extension question (that is, she examines the properties of the specific fact at hand to determine whether it is actually contained within the class of objects designated by the predicate).

These concepts are illustrated by Dworkin's famous example:

Suppose the legislature has passed a statute stipulating that 'sacrilegious contracts shall henceforth be invalid'. The community is divided as to whether a contract signed on Sunday is, for that reason alone, sacrilegious. It is known that very few of the legislators had that question in mind when they voted, and that they are now equally divided on the question of whether it should be so interpreted. Tom and Tim have signed a contract on Sunday, and Tom now sues Tim to enforce the terms of the contract, whose validity Tim contests. ${ }^{114}$

Suppose Tim and Tom agree they did sign a contract and did so on Sunday. The judge can conclude the existential statement, "Tom and Tim signed a contract on Sunday," is true. Under this assumption, the resolution of the dispute hinges on the issue of whether the contract between Tim and Tom is invalid because it is sacrilegious pursuant to the statute. To decide the issue, the judge must first determine the reliability of the

\footnotetext{
${ }^{110}$ Guastini, supra note 15 at 15-18. Although they use different terminology, others recognize the distinctive nature of the two steps. See e.g., Jerzy Wróblewski, Meaning and Truth in Judicial Decision (Helsinki: Juridica 1983); Aulis Aarnio, The Rational and the Reasonable: A Treatise on Legal Justification (Dordrecht: D. Reidel Publishing, 1987); Wilson, supra note 16 at 279.

${ }^{111}$ For a critical commentary of the usefulness of this distinction, see H Putnam, "The Meaning of 'Meaning", in Robert M Harnish, ed, Basic Topics on the Philosophy of Language (New York: Harvester Wheatsheaf, 1994) at 223.

${ }^{112}$ Michael BW Sinclair, "The Semantics of Common Law Predicates" (1985) 61 Ind LJ 3373 at 375.

113 Ibid.

${ }^{114}$ Ronald Dworkin, "No Right Answer?" (1978) 53 NYU L Rev 1 at 1.
} 
interpretive sentence, "The contract signed by Tom and Tim on Sunday is sacrilegious." The judge first determines the intension of the term "sacrilegious" - she must identify the attributes a contract must have to be qualified as sacrilegious (interpretation in abstract). Once the intension of the predicate "sacrilegious" is determined, the judge must determine whether the particular contract between Tom and Tim is sacrilegious (interpretation in concrete).

A closer look at "interpretation in abstract" and "interpretation in concrete" and at "intension" and "extension" sheds light on the differences between law-finding and factfinding. In addition, it shows that the distinction between "interpretation" and "application" fails to coherently distinguish between questions of fact and questions of law.

\section{Interpretation in abstract}

Interpretation in abstract, whereby the judge solves the intension question, differs from ascertainment of fact in several important respects. When engaged in interpretation in abstract, the judge examines the meaning of the predicate expression with no reference to the particular facts in issue. She asks what attributes are required for any particular fact $f$ to be contained within the meaning of the factual predicate $F$. In the previous example, the judge determines what attribute any contract must posses to be qualified as "sacrilegious", without reference to the particular contract between Tim and Tom. This clearly distinguishes interpretation in abstract from fact-finding, which focuses on ascertaining the truth or falsehood of descriptive existential statements concerning historical facts. In the example, the judge must determine the veracity of the existential statement "Tom and Tim signed a contract on Sunday." Three differences between interpretation in abstract and ascertainment of fact can be identified. First, the input of interpretation in abstract is a general description of the class of cases designated by the factual predicate, while the input of fact-finding is statements of evidence concerning individual empirical facts. Second, the outcome of the interpretation in abstract is interpretive sentences, while the outcome of fact-finding is existential statements concerning individual facts. ${ }^{115}$ Interpretive sentences are statements ascribing meaning to the relevant expressions contained in the legal language, while existential statements are propositions concerning the existence of empirical facts. Finally, the cognitive activity involved in assessing the reliability of interpretive statements differs from that involved in assessing the reliability of factual existential statements. In assessing the reliability of interpretive sentences, the judge applies semantic rules of language to determine the logical relationship between predicates. By contrast, when assessing the veracity of descriptive statements, the judge applies the logic of empirical evidence and follows the directives of proof mandated by the law.

When determining the intension of the factual predicate, the judge is confronted with a plurality of possible meanings stemming from the inherent indeterminacy of legal language. The choice of the relevant meaning hinges upon the choice of the interpretive

\footnotetext{
${ }^{115}$ Alchourrón and Bulygin, supra note 15 at 257. Eugenio Bulygin, "On Legal Interpretation" 53 Praktische Vernunft und Rechtsanwendung, ARSP-Beiheft (1991) 11 at 16.
} 
criterion, which is ultimately dictated by normative theories of legal interpretation. ${ }^{116}$ Alternative theories of interpretation might require taking into account matters such as the common usage of the language, the intention of the law-giving authorities, the context of the words, or the underlying policies and principles. The relevant normative theory of legal interpretation is generally dictated to the interpreter by the law. For example, the Canadian common law mandates judges adopt a contextualist approach to contractual interpretation.

\section{Interpretation in concrete (subsumption or classification)}

Once the intension of the factual predicate is determined, the interpreter must address the extension problem - that is, she must decide whether the case under consideration is included in the class of cases designated by the intension as previously defined. The extension question takes the form: "is $f$ contained within $F$ ?" 117

As previously noted, the judge solves the extension question through interpretation in concrete. The focus is not on the meaning of the factual predicate $F$ but on its logicalsemiotic correspondence with the historical fact $f$. This inferential step is also referred to in legal theory as "classification""118 or "subsumption."" The judge determines whether the fact in issue is subsumable into the class of facts identified by the factual predicate as previously interpreted. ${ }^{120}$ In the example, the extension question asks whether the particular contract between Tom and Tim is subsumable into the class of sacrilegious contracts.

Two forms of subsumptive reasoning must be distinguished: generic and individual. ${ }^{121}$ Generic subsumption occurs when the judge establishes that the class of objects to which the particular fact in issue belongs is subsumable into the class designed by the factual predicate. For example, the judge determines whether a class $X$ to which $f$ belongs is contained in $F$. Individual subsumption occurs when the judge establishes that the particular fact in issue is subsumable into the class of objects designed by the factual predicate. In the example, the judge determines whether $f$ is contained in $X$. The lack of appreciation of the distinct cognitive tasks involved in generic subsumption and individual subsumption is a major analytical shortcoming of using the conventional dichotomy between interpretation and application for distinguishing between question of fact and questions of law.

\footnotetext{
${ }^{116}$ Alexy, supra note 15; Chiassoni, supra note 15 at 49-168.

${ }^{117}$ The law judgment also involves the interpretation and application of the consequent. Here, the discussion is limited to the factual predicate, because it is relevant to the distinction between questions of fact and questions of law.

${ }_{118}^{118}$ MacCormik, supra note 15 at 95-97, 147-148, 197.

${ }^{119}$ See e.g., Karl Engish, Einführung in das Juristische Denken (Introduction to Legal Thinking) (Stuttgart; Kohlhammer, 1968) at 78-81; Wróblewski, supra note 15 at 190; Robert Alexy, "On Balancing and Subsumption. A Structural Comparison" (2003) 16 Ratio Juris 433; Frederick Schauer, "Balancing, Subsumption, and the Constraining Role of Legal Text," (2012) 4 L \& Ethics HR 35. The following discussion uses the terms "classification" and "subsumption" interchangeably.

${ }^{120}$ To be clear, the judgment also involves the interpretation and application of the consequent; however, the discussion is limited here to the factual predicate, as this is only the component of the legal rule relevant to the distinction between questions of fact and questions of law.

${ }^{121}$ Carlos Alchourrón and Eugenio Bulygin, Analisis logico y derecho (Logical Analysis and Law) (Madrid: Centro de Estudios Constitucionales, 1991) at 303; Alchourrón and Bulygin, supra note 16 at 256.
} 


\section{(a) Generic Subsumption}

The example above, in which the judge must determine whether the contract between Tom and Tim is sacrilegious, helps illustrate the distinction between generic subsumption and individual subsumption. After determining the meaning of the predicate "sacrilegious" (intension question-interpretation in abstract), the judge asks whether "contracts signed on Sunday" are contained within the class of sacrilegious contracts (extension question-interpretation in concrete). Based on the interpretation of the meaning of the predicate "sacrilegious," the judge may conclude that all the attributions necessary for a contract to be sacrilegious are present in contracts signed on Sunday, and therefore all contracts signed on Sunday are sacrilegious. This would be an example of generic subsumption, in which the judge subsumes the class of facts to which the fact in issue belongs (contracts signed on Sunday) into the extension of the factual predicate (sacrilegious contracts). The subsumption is generic because it creates a relationship between classes of facts (the contracts signed on Sunday and the sacrilegious contracts). Generic subsumption often provides the major premise of the deductive argument the judge uses to justify the application of a rule to the fact in issue. In the example, because it is established that Tim and Tom signed a contract on Sunday, the judge can conclude their contract is sacrilegious based on deductive reasoning:

1. All contracts signed on Sunday are sacrilegious;

2. Tim and Tom signed a contract on Sunday; therefore,

3. The contract between Tim and Tom is sacrilegious.

\section{(b) Individual Subsumption}

Now, suppose it is yet to be established that Tim and Tom signed a contract on Sunday; for example, Tim denies the document he and Tom signed on Sunday was a contract, or he denies that the contract was actually signed on Sunday. In this scenario, the generic subsumptive step discussed above (contract signed on Sunday are sacrilegious) is not sufficient to conclude that the contract between Tim and Tom is sacrilegious. After generically subsuming the category of contracts signed on Sunday into the category of sacrilegious contracts, the judge must determine whether the individual contract between Tim and Tom is subsumable into the category of contracts signed on Sunday. That is, interpretation in concrete involves individual subsumption - namely, to determine whether the individual fact in issue (document signed by Tim and Tom) is subsumable within the class of facts generically subsumed into the factual predicate (contracts signed on Sunday generically subsumed into the class of sacrilegious contracts). The judge must determine that the document signed by Tim and Tom is actually a contract and that it has been signed on Sunday. In general, interpretation in concrete may or not require individual subsumption depending on whether the description of the facts available to the judge provides sufficient information on their subsumability within the relevant factual predicate.

The difference between the cognitive tasks performed by the judge in generic and individual subsumption should be underlined. Generic subsumption establishes a logicalsemiotic relationship between classes of objects, based on the interpretation of the 
meaning of the relevant predicates. The input of generic subsumption is a class of objects $X$. Its outcome is a sentence of the form, " $X$ is contained in $F$." In the example, the input of generic subsumption is the class of contracts signed on Sunday; the output is the sentence "contracts signed on Sunday are sacrilegious." The reliability of generic subsumptive sentences is assessed based on the meaning of the predicate expressions alone (for example, "sacrilegious contracts") without reference to the particular facts of the case. ${ }^{122}$

By comparison, individual subsumption requires the interpreter determine whether an individual object is contained into a class of objects subsumable into the relevant predicate expression. The input of individual subsumption is the individual fact $f$. Its outcome is a sentence of the form " $f$ is contained in $X$." In the example, the input of individual subsumption is the document signed by Tim and Tom; the output is the sentence "the document signed by Tim and Tom is a contract signed on Sunday." Unlike generic subsumption, individual subsumption requires empirical information about the characteristics of the object in question. ${ }^{123}$ Because the judge establishes a connection between the specific fact at hand and the class of facts designed by the relevant predicate expression, the judge must not only apply semantic rules to establish logical relationships between predicates, but must also use information about the particular fact at hand. In the example, the judge must use information concerning the day the contract was signed, or concerning the content of the documents actually signed by Tim and Tom.

The nature of the cognitive task involved in individual subsumption change depending on whether the judge is confronted with a gap in empirical knowledge or a gap in semantic recognition. ${ }^{124}$ In the former, difficulties arise due to insufficient empirical information on the properties of the individual fact in issue. In the above example, Tim and Tom may not agree on when they signed a contract or on what documents they actually signed. The judge must gather evidence reflecting exactly what happened between the parties. In the latter, difficulties might stem from the semantic indeterminacy of the relevant predicate expression, even with full empirical knowledge of the relevant primary facts. ${ }^{125}$ For example, even if Tim and Tom agree on what document they signed and when they did so, they may disagree on whether that document was actually a contract. Tim may claim it was a non-binding preliminary agreement. The judge is confronted with a gap in recognition; to solve the individual subsumption problem she must engage in an interpretive exercise to decide whether the document signed on Sunday is included in the extension of the predicate "contract." The difference between gaps of empirical

\footnotetext{
${ }^{122}$ It is useful to note that generic subsumption is, at the same time, an essential component of interpretation in abstract (because it requires establishing a relationship between the intension of two predicates independent of the individual fact in issue) and a logical preliminary step to interpretation in concrete (because the fact in issue cannot be subsumed into the factual predicate if it is not "generically" subsumed).

${ }^{123}$ Wilson, supra note 16 at 279.

${ }^{124}$ Alchourrón and Bulygin, supra note 15 at 31; Alchourrón and Bulygin, supra note 16 at 256.

${ }^{125} \mathrm{Ibid}$. It should be noted that gaps in empirical knowledge also occur with respect to generic subsumption. The judge may require more factual information on the empirical properties of the category of objects named by the factual predicates. However, there is a clear structural difference relevant to the fact-law distinction. The empirical knowledge required in generic subsumption pertains to the class of facts defined in the factual predicate - it therefore refers to statistical regularities. Meanwhile, the empirical knowledge required in individual subsumption pertains to the individual fact at issue.
} 
knowledge and gaps of semantic recognition help categorize questions along the fact-law spectrum.

\section{The failures of the traditional dichotomy between interpretation and application}

The preceding discussion illuminates two important points that the traditional dichotomy between interpretation and application fails to convey. First, interpretation in abstract and generic subsumption are structurally similar. ${ }^{126}$ Both types of cognitive activities involve deciphering the meaning of predicates without reference to the particular facts of the case. Both require the judge to establish a logical relationship between predicates by applying semantic rules. From this perspective, generic subsumption can be conceptualized as establishing a relationship between the intensions of two predicates (two "abstract" facts), and therefore structurally similar to interpretation in abstract.

Second, it is worth repeating, there is a structural difference between the cognitive tasks performed by the judge in generic subsumption and individual subsumption, respectively. While in generic subsumption, the judge draws a semantic relationship between two predicates $(X$ and $F)$, in individual subsumption the judge establishes a semantic relationship between a concrete object and a predicate $(f$ and $X)$. This distinction marks a critical difference in the judicial cognitive task. Unlike generic subsumption, individual subsumption requires empirical information about the characteristics of the individual object in question.

\footnotetext{
${ }^{126}$ The structural similarity between generic subsumption and interpretation in abstract is emphasized in MacCormik, supra note 15 at 95 . MacCormik does not distinguish between individual and generic subsumption (he collapses them into the notion of "classification"); however, his account of adjudicative reasoning recognizes the judicial task involved in interpreting the meaning of a term and solving the problem of whether or not to classify the proven primary facts similarly belong within the category of facts described in the factual predicate.
} 
Table 1. Cognitive tasks involved in adjudication

\begin{tabular}{|c|c|}
\hline Fact-Finding & Law-Finding \\
\hline $\begin{array}{l}\text { Facts Descriptively Determined } \\
\text { - } \begin{array}{l}\text { Determination of the truth or falsehood } \\
\text { of descriptive existential statements }\end{array}\end{array}$ & $\begin{array}{l}\text { Interpretation in Abstract } \\
\text { - Determination of the intension of the } \\
\text { factual predicate }\end{array}$ \\
\hline $\begin{array}{l}\text { Facts Evaluatively Determined } \\
\text { - Determination of the truth or falsehood } \\
\text { of descriptive existential statements } \\
\text { - Choice of axiological/normative criteria } \\
\text { - Individual value judgment }\end{array}$ & $\begin{array}{l}\text { Interpretation in Concrete } \\
\text { - Determination of the extension of the } \\
\text { factual predicate } \\
\text { Generic Subsumption } \\
\text { O Subsuming a class of object into } \\
\text { the extension of the factual } \\
\text { predicate } \\
\text { Individual Subsumption } \\
\text { Subsuming an individual object } \\
\text { into the extension of the factual } \\
\text { predicate by resolving either a gap } \\
\text { in empirical knowledge or a gap in } \\
\text { semantic recognition }\end{array}$ \\
\hline
\end{tabular}

\section{CATEGORIZING QUESTIONS}

In light of the considerations outlined above, this subsection provides a framework for categorizing the various steps of adjudicative reasoning along the fact-law spectrum. The need for economizing scarce judicial resources suggests a question should be treated as a question of fact, and as such reviewed on a deferential standard on appeal, when the trial judge enjoys a relative institutional advantage in accomplishing the relevant cognitive task required by the particular findings at issue. The source of this advantage is often found in the structure of the costs associated with gathering the information required to accomplish the task. ${ }^{127}$ By contrast, a question should be treated as a question of law when the appellate court enjoys a relative institutional advantage over the trial judge, as often occurs when the task engages the lawmaking function of appellate courts. Based on these allocative criteria the various cognitive tasks involved in adjudicative reasoning can be placed along the fact-law spectrum.

\section{Identifying questions of fact}

In fact-finding, the cognitive task is to establish the truth or falsehood of the existential statements concerning the relevant facts. The informational advantage enjoyed by the judge is, at least to some extent, a function of the type of fact as determined by the legal language. The distinction between facts determined descriptively, facts determined evaluatively, and facts proved by circumstantial evidence has a special bearing upon the relative institutional advantages of trial judges versus appellate courts.

\footnotetext{
${ }^{127}$ It is widely believed that trial and appellate courts differ in their epistemic capabilities. This proposition is not discussed in this paper. Here, it is assumed they enjoy the same epistemic capabilities and that the only sources of relative advantage are institutional, namely, the different roles assigned by the institutional framework.
} 


\section{(a) Facts determined descriptively}

It is widely recognized that the trial judge enjoys a relative institutional advantage over appellate courts in gathering empirical evidence. The trial judge directly hears the facts, observes the witnesses, and, more generally, weighs the evidence proffered by the parties by immersing herself in the evidence in a way that an appellate court cannot do. ${ }^{128}$ As such, the trial judge is in the best position to conduct fact-finding to the extent it involves hearing the facts, observing the witnesses, and, on this basis, assessing empirical evidence.

When the facts in issue are descriptively determined, the task of the judge is to evaluate the truth or falsehood of the corresponding existential statements by assessing the statements of empirical evidence produced by the parties and linking them by directives of proof. Therefore, the trial judge should assume primary responsibility in the ascertainment of the facts. When the primary facts at issue are descriptively determined, the appellate court's deferential attitude toward the trial judge's finding of fact is justified.

\section{(b) Facts determined evaluatively}

Facts determined evaluatively involve 1) an existential descriptive statement, 2) the axiological criteria, and 3) a value judgment about the individual fact. The categorization of issues involving the ascertainment of these types of facts should distinguish between these three elements.

The decision on the truth or falsehood of existential descriptive statements concerning the empirical basis of the facts evaluatively determined is no different than that concerning any fact descriptively determined and should therefore be treated as a question of fact. The choice of the axiological criteria hinges on political, social, or moral directives upon which appellate courts are as well placed as the trial judge to decide. This choice is not related to the gathering of evidence, but involves considerations inherent in the lawmaking function, a primary function of appellate court. It should therefore be regarded as question of law. Meanwhile, the individual value judgment may involve either questions of law or questions of fact. Here, the distinction between generic and individual subsumption helps distinguish questions of fact and questions of law. Generic subsumption involves questions of law, as it does not require the judge to engage in the gathering or assessment of empirical evidence. Individual subsumption may involve either questions of fact or questions of law depending on whether the judge faces a gap in empirical knowledge or a gap in recognition.

\section{(c) Facts determined by means of circumstantial evidence}

Historically, appellate courts accorded less deference to findings of fact based on inferences from secondary facts than to findings of fact based on the credibility of witnesses. ${ }^{129}$ This distinction is no longer recognized in Canadian law. ${ }^{130}$ Housen holds

\footnotetext{
${ }^{128}$ Drewry et al., supra note 17 at 23-30; Gibbens, supra note 17 at 446.

${ }^{129}$ Gibbens, supra note 17 at $449-451$.
} 
that inferences of fact are no different from findings of fact. ${ }^{131}$ Both are reviewed on a standard of palpable and overriding error.

Yet questions of law may be involved in the inference-drawing process. First, issues about the admissibility of evidence are characterized as questions of law reviewed on correctness. They must therefore be distinguished from issues concerning the weighing of evidence, which are protected from review. Second, a question of law arises when the judge has clearly disregarded relevant evidence in proceedings where the entire record consists of documentary or written evidence. In such proceedings, the appellate court may interfere with a lower court's finding of fact. Finally, when the inference relies on assumptions pertaining to social facts, it involves a question of law on which the reviewing court should make its own assessment.

The presence of normative judgments in the inference-drawing process casts doubts on Housen according the same degree of deference to "all factual conclusions made by the trial judge." 132 It is not clear whether the policy rationale for deference on appeal holds when legal inferences are drawn from established facts.

\section{Identifying questions of law}

It is generally recognized that a standard of correctness should apply to questions of law. The primary justification for the application of this standard is that questions of law engage the appellate courts' primary function; namely, to ensure that rules are applied uniformly and consistently. Based on this premise, a question is qualified as a question of law if it involves either the identification of the relevant legal rule or interpretive statements of the relevant law made by judges. This proposition should be further qualified in light of the previously developed account of law-finding, based on the distinctions between interpretation in abstract, interpretation in concrete, generic subsumption, and individual subsumption. ${ }^{133}$

There is little doubt that interpretation in abstract involves questions of law, as it focuses on defining the intension of factual predicates. It does not entail the use of empirical evidence; it rather involves an interpretive exercise requiring the understanding of a variety of factors, including the purpose of the relevant law and the policies, principles, and value judgments underlying it. The trial judge has no particular advantage over the appellate court in interpreting the meaning of the relevant predicate expression. Questions of law also arise in fact-finding with respect to facts evaluatively determined. The choice of the axiological criteria used to define these facts hinges upon political, social, or moral directives. This engages the lawmaking function of the courts, which is one of the

\footnotetext{
${ }^{130}$ TS Woods, "Overturning Findings of Fact on Appeal: A Justifiably Narrow Jurisdiction" (1998) 56 Advocate 61 at 67.

${ }^{131}$ Housen, supra note 17 at para 25

${ }^{132}$ Housen, supra note 17 at para 25.

${ }^{133}$ It is useful to note that in the judgment of appeal, the identification of the prima facie applicable rule (the first step above) plays out differently than in the trial judgment. The appellate court enjoys the benefit of reconsidering the case in light of both the factual findings and the legal analysis undertaken by the trial judge. In this sense, the appellate court does not engage in a "prima facie" identification of the relevant rule. Once deference is accorded to the trial judge's factual findings, the identification of the legal rules governing the case is based on the formulation by the appellate court of interpretive and subsumptive statements.
} 
primary institutional tasks of appellate courts. The choice of the axiological criteria should therefore be regarded as a question of law.

The most contentious point concerns the proper characterization of interpretation in concrete, whereby the judge determines the extension of the relevant predicate expressions. Conventional legal language refers to this activity as the application of the legal rule to a set of facts. Certain authors contend the application of law to the facts in issue is a question of fact. ${ }^{134}$ Others maintain the process of applying the law is legal in nature and therefore involves questions of law. ${ }^{135}$ Canadian case law characterizes issues of law application as questions of mixed fact and law reviewed on a deferential standard, unless an extricable error of law is identified. It is contended here that the category of "application of the law" to the facts in issue is analytically imprecise and falls short of capturing the heterogeneity of the cognitive steps performed by the judge.

The tasks performed by the judge in dealing with the extension problem include both generic and individual subsumption. Because it is structurally similar to interpretation in abstract, trial judges are in no better position to perform the type of interpretive activity involved in generic subsumption. Generic subsumption should therefore be characterized as a question of law. The nature of the cognitive task involved in individual subsumption changes significantly depending on whether the judge is confronted with a gap in semantic recognition or a gap in empirical knowledge. Individual subsumption should be treated as a question of law when it entails a gap in recognition and as a question of fact when it depends on a gap of empirical knowledge. It is misguided to use the "application of the law" category without carefully considering each of these elements.

Table 2. Proposed categorization of issues

\begin{tabular}{|c|c|}
\hline Questions of Fact & Questions of Law \\
\hline $\begin{array}{l}\text { - Statements of facts determined descriptively } \\
\text { - Statements of facts concerning the empirical } \\
\text { basis of facts determined normatively } \\
\text { - Factual inferences involved in the judicial } \\
\text { ascertainment of facts } \\
\text { - Individual subsumptive sentences when a } \\
\text { gap of empirical knowledge is involved }\end{array}$ & $\begin{array}{l}\text { - } \text { Admission of evidence } \\
\text { - } \text { Failure to consider relevant evidence } \\
\text { - } \text { Inferences from social facts } \\
\text { - Choice of axiological criteria involved in the } \\
\text { judicial ascertainment of facts evaluatively } \\
\text { determined } \\
\text { - Interpretive sentences defining the intension } \\
\text { - } \text { of factual predicates } \\
\text { - Individual subsumptive sentences when a } \\
\text { gap in semantics recognition is involved }\end{array}$ \\
\hline
\end{tabular}

\section{E CRITIQUE OF THE HOUSEN CATEGORIZATION}

The analytical framework developed in this section shows several difficulties associated with Sattva's approach to deference can be traced back to Housen's categorization of

\footnotetext{
134 Thayer, supra note 16 ("It seems that there is no occasion to speak of them [questions of law and fact] as anything other than mere matters of fact").

${ }^{135}$ Holmes, supra note 21 at 122 and 129.
} 
questions. In Housen, the choice between a deferential and non-deferential standard of review hinges upon the distinction between "identification of the relevant legal test" (reviewed on correctness) and "application of the test to the facts" (reviewed deferentially). The discussion so far has shown this distinction creates four weaknesses that must be addressed.

1 The inadequacy of the degree of generality as a criterion for distinguishing between questions of fact and questions of law

Housen rests on the principle that the key difference between a question of law and a question of mixed fact and law must be found in the degree of generality of the relevant issue. ${ }^{136}$ However, the degree of generality alone does not offer a valid criterion for distinguishing between questions of fact and questions of law. One needs to previously identify a criterion for determining the relevant degree of generality and the elements of fact pertaining to this assessment. Absent these prior determinations, the degree of generality provides no guidance to the fact-law distinction. Furthermore, this principle assumes the predominant purpose of appellate courts is to ensure uniformity and consistency of the law (the lawmaking function) rather than to certify better outcomes in individual cases (the error-correcting function). However, appellate courts have historically pursued both functions. ${ }^{137}$

2 The structural similarity between generic subsumption and interpretation in abstract Housen fails to fully appreciate the structural similarity between interpretation in abstract and generic subsumption: while the former is treated as a question of law reviewed on correctness, the latter is qualified as a mixed question to be reviewed deferentially. The practical consequence of Housen's framework is to accord a different treatment to similar judicial cognitive processes.

\section{The structural differences between generic subsumption and individual subsumption} By holding that the application of a legal standard to a set of facts involves generally questions of mixed fact and law to be reviewed deferentially, Housen fails to appreciate the structural differences between generic and individual subsumption. The Court argues the process of applying a rule to the facts is "intertwined with the weight assigned to the evidence" and therefore the policy reasons for deference hold. ${ }^{138}$ However, while generic subsumption involves establishing a relationship between classes of cases, the latter requires subsuming a particular fact within a class of cases. While it is justifiable to accord deference to the trial judge's individual subsumption propositions when a gap in empirical knowledge is involved, there is no rational basis to do so for generic subsumptive findings. Here, Housen's framework offers a similar treatment to different judicial cognitive processes.

\footnotetext{
${ }^{136}$ Housen, supra note 17 at para 28

${ }^{137}$ Drewry et al., supra note 17 at 20-22.

${ }^{138}$ Housen, supra note 17 at para 32.
} 
4 Questions of law are involved in fact-finding when evaluatively determined facts are involved

Housen fails to appreciate that a judicial ascertainment of fact may involve questions of law when facts evaluatively determined are involved. As previously clarified, while the truth or falsehood of the descriptive existential statement is a question of fact, the choice of the axiological criteria and the value judgment about the individual fact involve questions of law. Table 3 summarizes the discussion by comparing Housen's categorization with the one proposed here.

Table 3. Housen v. the proposed categorization of judicial cognitive tasks

\begin{tabular}{|c|c|c|c|c|}
\hline \multicolumn{3}{|c|}{ Housen } & \multicolumn{2}{|c|}{ Proposed Framework } \\
\hline $\begin{array}{l}\text { Questions } \\
\text { of Fact }\end{array}$ & Mixed Questions & $\begin{array}{l}\text { Questions } \\
\text { of Law }\end{array}$ & $\begin{array}{l}\text { Questions of } \\
\text { Fact }\end{array}$ & Questions of Law \\
\hline $\begin{array}{l}\text { Descriptive } \\
\text { existential } \\
\text { statements } \\
\text { Inference } \\
\text { drawing }\end{array}$ & $\begin{array}{l}\text { Generic subsumption } \\
\text { Individual } \\
\text { subsumption }\end{array}$ & $\begin{array}{l}\text { Interpretation } \\
\text { in abstract }\end{array}$ & $\begin{array}{l}\begin{array}{l}\text { Descriptive } \\
\text { existential } \\
\text { statements }\end{array} \\
\text { Inference drawing } \\
\text { Individual } \\
\text { subsumption with } \\
\text { gap in empirical } \\
\text { knowledge }\end{array}$ & $\begin{array}{l}\text { Evaluative judgment } \\
\text { involved in the judicial } \\
\text { ascertainment of facts } \\
\text { Interpretation in } \\
\text { abstract } \\
\text { Generic subsumption } \\
\text { Individual subsumption } \\
\text { with gap in recognition }\end{array}$ \\
\hline
\end{tabular}

\section{Categorizing Contractual Interpretation Issues}

This section applies the analytical framework developed in the preceding section to contractual interpretation. It examines the theoretical weaknesses underpinning Sattva's line of reasoning, then provides a framework for distinguishing questions of fact from questions of law in contractual interpretation. It also explores the recent evolution of the provincial court of appeals' case law, which is increasingly inconsistent with Sattva's deferential approach. The analysis of the court of appeals' case law provides an important lesson. The growing list of extricable errors of law identified by appellate courts confirms the standard of review on contractual interpretation issues should not flow from the general qualification of contractual interpretation as a mixed question, but it should rather be based on a careful characterization the narrow interpretive issue actually in dispute.

\section{A CRITIQUING SATTVA'S CATEGORICAL APPROACH}

Sattva's categorical statement that contractual interpretation generally involves questions of mixed fact and law rests upon four related assumptions: 1) contractual interpretation issues have limited precedential value; 2) ascertaining the parties' intent is a factual matter; 3) the relevance of the factual matrix accentuates the fact-specific nature of contractual interpretation issues; and 4) contractual interpretation appears closer to a 
question of mixed fact and law, defined as applying a legal standard to a set of facts. Each of these assumptions is now critically examined.

\section{The precedential value of contractual issues}

In Sattva, the main reason for deference to the trial judge's interpretation of a contract is that contractual interpretation issues are characterized by low precedential value, being of interest only to the particular parties. The relevant passage is worth quoting:

The legal obligations arising from a contract are, in most cases, limited to the interest of the particular parties. Given that our legal system leaves broad scope to tribunals of first instance to resolve issues of limited application, this supports treating contractual interpretation as a question of mixed fact and law. ${ }^{139}$

This is a non sequitur. The fact that contractual obligations are limited to the interest of the contractual parties does not support the conclusion that contractual interpretation issues have low precedential value. Contractual obligations stem from an agreement between two or more private parties and are generally enforceable only by or against the parties to the contract. In this sense, legal obligations arising from contracts are often "limited to the interest of the particular parties." This does not imply, however, that contractual interpretation issues do not have precedential value. Contractual interpretation involves questions about the meaning of the words of the contract. These questions, as stated previously, require defining the intension of predicates contained in the words of the contract. Intension refers to classes of objects. Hence, the judge's determination of the intension of a word contained in a particular contract may be applied to future contractual relationships involving the use of that expression. Of course, the meaning of a given expression is context-dependent; it may change from case to case. This is not enough to justify the proposition that questions concerning the interpretation of the words of contract are of limited application to future cases. The precedential value of contractual interpretation issues cannot be equated, or conflated, with the precedential value of issues concerning the existence or enforceability of obligations arising from a particular contract.

\section{Ascertaining contractual intention}

One might argue that questions of contractual interpretation still have limited precedential value, because determining contractual intent is essentially a factual exercise. The Supreme Court emphasizes that contractual interpretation is a "factspecific" exercise whose main goal is to ascertain the objective intention of the parties. ${ }^{140}$ However, there is conceptual tension between the objectivist approach to contractual intent adopted in the Canadian case law $^{141}$ and the qualification of contractual intent as a factual matter.

As a theoretical matter, the nature of contractual intent is characterized differently depending on whether a subjectivist or objectivist approach to contractual interpretation is

\footnotetext{
139 Sattva, supra note 1 at para 52 (emphasis added).

${ }^{140} \mathrm{Ibid}$ at para 49.

${ }^{141}$ It is a well settled principle in Canadian common law that when interpreting a contract the court's search for the intention of the parties is aided by reference to the factual matrix as viewed objectively by a reasonable person at the time of contract execution; see supra note 26.
} 
adopted. According to subjectivist theory, the target of contractual interpretation is the empirical, subjective intent of the contracting parties. The relationship between text and intention is one between secondary fact and primary fact. The judge uses the text and context of the contract to draw empirical inferences on what the parties had in mind when writing the relevant contract language. ${ }^{142}$ Text and context provide circumstantial evidence of the subjective intent of the parties. ${ }^{143}$ In this view, contract interpretation is a backward-looking activity whose underlying logic rests on an empirical foundation of descriptive statements. The task of determining the contractual intent pertains to the factfinding.

Contrast this with the objective theory of contractual intent, in which the intention of the parties matters to the extent it is made recognizable to the external observer through the use of a linguistic code. Intent matters to the extent it is "objectivized." ${ }^{144}$ The target of contractual interpretation is not the subjective intent of the parties (their actual understanding of the text they adopted), but rather the content of the agreement as reflected by the parties' linguistic choices (the meaning of the contract as viewed objectively by a reasonable person at the time of contract formation). The contract's text is not a secondary fact, from which contractual intent must be inferred; it constitutes the very object of contractual interpretation. ${ }^{145}$ Under these theoretical assumptions, it is less clear that contractual intent should be regarded as a factual matter. Contractual intent requires formulating interpretive statements concerning the meaning of the words of the contract. The meaning-ascribing activity is hermeneutic in nature and properly qualified as a legal matter. ${ }^{146}$

The preceding considerations illuminate an important weakness of the Sattva line of reasoning. Sattva expressly adopts an objective approach to contractual interpretation. However, instead of fully appreciating its consequences and carefully inquiring into what extent the objective style of interpretation is compatible with the deferentialist approach on appeal, the Supreme Court hastily concludes that the deferentialist approach generally applies to issues of contractual interpretation. This conclusion is unwarranted. While the generalization of the deferential standard on appeal would be consistent with a subjective approach to contractual interpretation, under the objectivist framework, a general deferential rule should be justified and argued for more carefully considering the normative nature of contractual intent.

\footnotetext{
${ }^{142}$ Burton, supra note 19 at 51.

${ }^{143}$ The relationship between the words of the contractual document and the contractual intent is the same that exists between factum probans and factum probandum: text and context are the factum probans, while parties' subjective intent is the factum probandum.

${ }^{144}$ The objectivization of the parties' intentions enables the realization of a number of normative goals, including the pursuit of legal certainty and the protection of the parties' reliance on the other's statement or promise.

${ }^{145}$ This point is well clarified in Piero Schlesinger, "Interpretazione del Contratto e Principio Dispositivo," (Contractual Interpretation and the Adversarial Principle) "Temi” (1963) 6, 1135.

${ }_{146}$ One could still object that contract rules are "agreed upon" by the parties and therefore their meaning could be only construed by making reference to the parties' subjective intent at the moment of contract formation. This misses the point. Once the logic of objectivization of contractual intent is recognized, the task of the interpretive endeavour becomes that of identifying the content of the agreement as reflected in the linguistic choices made by the parties at the moment of contract formation. Therefore, although contractual rules are the expression of parties' private autonomy (they are "agreed-upon" rules), they are still rules whose meaning is determined through a hermeneutic effort, and not through empirical inference of the parties' subjective intention.
} 


\section{The juridical relevance of the factual matrix}

In Sattva, the Court establishes a correlation between the qualification of contractual interpretation as a mixed question and the central relevance of the factual matrix in contractual interpretation. However, the correlation between the intensified relevance of the factual matrix and the mixed fact and law nature of contractual interpretation is debatable.

The factual or legal nature of the inferences drawn from the factual matrix depends on the theory of contractual interpretation. Under the subjectivist approach, the judge employs the factual matrix to draw empirical inferences of the parties' subjective intention. Under the objectivist approach, the judge uses the factual matrix to draw legal inferences of the reasonable meaning of the words of the written contract. It is widely recognized, both scholarly and jurisprudentially, that the Canadian legal regime of contractual interpretation is informed by the theory of contextual objectivism, in which the factual matrix is used to deepen the interpreter's understanding of the objective intention of the parties. ${ }^{147148}$ The objectivist framework suggests caution in qualifying as "factual" the inferences drawn from the surrounding circumstances of the contract.

\section{Conflating contractual interpretation and law application}

Finally, Sattva argues that, as contractual interpretation consists of applying the legal principles of interpretation to the words of the written contract, it appears to be similar to a question of mixed fact and law, defined in Housen as "applying a legal standard to a set of facts." 149 This argument is misguided. In contractual interpretation the principles of legal interpretation are not "applied to a set of facts" as Housen describes; they rather inform an interpretive process. It is one thing to apply the principles of legal interpretation to the process of contractual interpretation, and another to apply the words of the contract (as previously interpreted) to the facts in dispute. The former does not entail the application of rules to a set of facts, as the definition of questions of mixed law and fact suggests; it involves the exercise of an interpretive process in a manner consistent with a set of legal principles. Blair J.A., writing for the majority in Bell Canada, was correct when questioning whether Housen was at all applicable to contractual interpretation. ${ }^{150}$

\section{B IDENTIFYING CONTRACTUAL TERMS}

The theoretical weaknesses underpinning Sattva's categorical statement that contractual interpretation generally involves questions of mixed fact and law have been identified. A further problematic aspect of Sattva is that it considers the process of contractual interpretation as an indistinct whole, without distinguishing its various components. It is suggested here that a coherent categorization of the nature of contractual interpretation issues requires a more careful identification of the various and distinct steps performed

\footnotetext{
${ }^{147}$ See case law mentioned supra note 26 and the comment supra note 141. It is useful to note that the objective approach to contractual interpretation is confirmed by the Court in Sattva, supra note 1 at para 57.

${ }_{148}^{14}$ Sattva, supra note 1 at para 57.

${ }^{149}$ Sattva, supra note 1 at para 49.

${ }^{150}$ Bell, supra note 40 at paras 24-25.
} 
by the judge in contractual interpretation. This allows better discernment of the cognitive tasks involved in contractual interpretation and shows that while certain issues may be characterized as factual in nature, other aspects of contractual interpretation require no fact-finding.

Based on this premise, it is useful to distinguish four sequential steps performed by the judge within the process of contractual interpretation: 1) identify the terms of the contract, 2) ascertain the existence of any ambiguity in the contractual terms, 3) resolve any such ambiguity, and 4) apply the terms of the contract to the concrete case at hand. ${ }^{151}$ While these four steps are not recognized as distinctive components of the contractual interpretation process under Sattva, it is argued here that this approach provides a better understanding of the actual process of contractual interpretation judges normally employ. A brief analysis of each of the four steps shows how contractual interpretation issues should be placed along the fact-law spectrum depending on the nature of the cognitive task involved. Furthermore, it is shown that the proposed methodology is largely consistent with the list of extricable errors of law identified by appellate courts.

The first step taken by the judge in contractual interpretation matters is to determine the terms of the contract. Under Canadian common law, the identification of contractual terms is largely governed by the parol evidence rule. ${ }^{152}$ According to this rule, when the written document represents the final and exclusive record of the parties' agreement, extrinsic statements and promises that add to, subtract from, vary, or contradict the written contract are not admissible. ${ }^{153}$ Based on Sattva's categorization, the identification of contractual terms should be qualified as a mixed question to be reviewed deferentially because it appears closer to a question of mixed fact and law as defined in Housen due to its application of the parol evidence rule to the facts of the case. The conceptual framework proposed here suggests this is imprecise.

The factual predicate of the parol evidence rule dictates it applies when a written document is to be regarded as the final and exclusive record of the parties' agreement. ${ }^{154}$

\footnotetext{
${ }^{151}$ Burton, supra note 19.

${ }^{152}$ The Supreme Court of Canada affirmed the parol evidence rule in Harwish v. Bank of Montreal [1969] S.C.R. 515 and Bauer v. Bank of Montreal [1980] 2 S.C.R. 102, [1980] 2 R.C.S. 102. In Sattva, Justice Rothstein emphasized that the parol evidence rule is "of limited application in view of the myriad of exceptions to it" [para 61]). In light of both this latter consideration and the central relevance of the factual matrix that Sattva itself reaffirmed, some commentators have argued that the parol evidence rule is fundamentally at odds with the contextualist approach to contractual interpretation; see e.g., Hall, supra note 5 at 73 and 76. However, it must be recognized that there is no contradiction between the parol evidence rule and the central relevance of the factual matrix. While the parol evidence rule concerns the identification of contractual terms, the factual matrix is considered for ascribing meaning to contractual terms. Therefore, the adoption by Canadian courts of the contextual approach to contractual interpretation does not per se involve the abandonment of the parol evidence rule. This is confirmed in Sattva, where Justice Rothstein emphasizes that "[t]he parol evidence rule does not apply to preclude evidence of the surrounding circumstances" [at para 60].

${ }^{153}$ For a classic textbook definition of the parol evidence rule, see Arthur Linton Corbin and Joseph M. Perillo, Corbin on Contracts (St. Paul: West Publishing Company, 1952) at 534. With respect to Canadian law, see John D. McCamus, "The Law of Contracts, 2nd ed (Toronto: Irwin Law, 2012) at 197-211; Hall, supra note 5 at 73-87; Swan, supra note 7 at $751-769$

${ }^{154}$ Several commentators emphasize the distinction between two different versions of the parol evidence rule; see S Waddams, "Two Contrasting Approaches to the Parol Evidence Rule" (1987) Can Bus LJ 206; McCamus, supra note 153 at 197-203 and 206-209. The difference between the two versions of the rule lies in different understandings of its factual predicate. According to the "traditional" approach, the parol evidence rule applies where the written agreement appears to be complete on its face. In this case, parties are not admitted to provide evidence of contractual terms that
} 
For brevity this can be referred to as the "integrated" (or "conclusive") agreement. ${ }^{155}$ To determine the applicability of the parol evidence rule, the judge must first decide whether a written document is to be regarded as integrated. This fact, evaluatively determined, comprises several steps. First, the judge must determine the truth or falsehood of existential statements concerning the communication that occurred between the parties regarding the conclusiveness of their written document. This step is not determinative of whether the contract is fully integrated. The judge simply establishes what happened between the parties based on the relevant evidence. ${ }^{156}$ This determination should be regarded as a question of fact.

Second, the judge must formulate the normative principle, on the basis of which it is established that a written document can be regarded as the conclusive record of an agreement. That is, she must define the intension of the "conclusive" or "integrated" agreement by identifying the attributes an agreement must have to be included in such a class of agreements (interpretation in abstract). To undertake this step, the judge relies on legal principles related to the parol evidence rule. This exercise is riddled with interpretive difficulties tracing back to a lack of an agreed formulation of the rule itself ${ }^{157}$ and a long list of instances where courts recognize the rule to be not applicable. ${ }^{158}$ The determination of the scope of the parol evidence raises a question of law reviewable on a standard of correctness. This conclusion is consistent with current case law. In King, the Manitoba Court of Appeal stated, "[D]etermining the legal principles related to the parol evidence rule raises a question of law reviewable on a standard of correctness." 159

Third, the judge must undertake a judgment about the individual fact (or interpretation in concrete) and determine whether the written document at hand is conclusive or integrated. This may require the judge to solve a generic subsumption problem, such as deciding whether a contract signed by the parties and stating expressly that it is the final and exclusive expression of their agreement is to be considered an integrated contract. ${ }^{160}$ This is a delicate interpretive question that requires the judge to establish a logicalsemiotic relationship between the class of "integrated contracts" (as previously defined in abstract) and the class of "contracts signed by the parties and stating that they are final

\footnotetext{
are oral and have not been reduced to writing. According to the "modern" approach, the presence of a written agreement that appears complete on its face gives rise to a presumption that the written document represents the final and exclusive record of the parties' agreement. The presumption is rebuttable, and parties are therefore admitted to provide (oral or written) evidence of the parties' intent to not regard the written document as the final and exclusive record of their agreement. The distinction between the two approaches is not explicitly articulated in Canadian case law; however, there is a tendency by Canadian courts to move toward the adoption of the modern rule; see, for example, Gallen v. Butterley, [1984] B.C.J. No. 1621, 9 D.L.R. (4th) 496; Nevin v. British Columbia Hazardous Waste Management Corp. [1995] B.C.J. No. 2301|129 D.L.R. (4th) 569.

${ }^{155}$ Swan, supra note 7 at 753

${ }^{156}$ The parol evidence rule does not preclude the use of parol evidence to address the question of integration. The judge can rely on the parol evidence in determining whether the agreement is integrated (for example, antecedent agreements, negotiations, and oral understandings); Waddams, supra note 154 at 208; S Waddams "Do We Need a Parol Evidence Rule?" (1991) 19 Can Bus LJ 385 at 395; Swan, supra note 7 at 757. Once the judge has determined, on the basis of all extrinsic evidence, that the contract is integrated, parol evidence will not be admitted at the subsequent stage of establishing the meaning of contractual terms.,

${ }^{157}$ See supra note 154 at

${ }^{158}$ Hall, supra note 5 at 76-77; Swan, supra note 7 at 755.

${ }^{159}$ See supra note 22 at para 29.

${ }^{160}$ Waddams, 1991, supra note 156 at 395 and 388-390.
} 
and conclusive." The underlying interpretive issue the judge must resolve is the meaning and legal significance of the signatures. This is a question of law reviewable on a standard of correctness.

In other cases, the interpretation in concrete does not involve a complex generic subsumptive step and comes down to individual subsumption. The judge assesses whether the factual findings concerning the communication between the parties support the proposition that the parties agreed that the document was to be conclusive. This is a determination of the subjective intent of the parties on the basis of the available extrinsic evidence. ${ }^{161}$ It is question of fact to be reviewed deferentially. This is of critical importance. Often, as Waddams observes, appellate courts use the parol evidence rule "to reverse a trial judge's decision in favor of the signer where the appellate court simply does not agree with the judge's finding of fact."162 This is a distorted use of the rule that inappropriately alters the allocation of labour between trial judges and appellate courts, as it overrides the distinction between evidence designed to show the intention of the parties as to whether the contract is conclusive (admissible evidence) and evidence used to establish the terms of the contract (inadmissible if the contracted is integrated). ${ }^{163}$

\section{IDENTIFYING CONTRACTUAL AMBIGUITIES}

Once the judge has identified the terms of the contract, she must give them meaning. The judge must identify any relevant ambiguity, which occurs when the terms of the contract are susceptible to more than one reasonable meaning proffered by the parties. ${ }^{164}$ Before examining whether the ambiguity issue must be qualified as a question of fact or a question of law, intrinsic ambiguity must be distinguished from extrinsic ambiguity. While the former is an ambiguity that is clear on its face, the latter refers to an ambiguity established by reference to the backgrounds facts.

Traditionally, the notion of intrinsic ambiguity is found in common law as a precondition to considering the factual matrix for the purpose of contractual interpretation. Many early cases indicate judges may consider the surrounding circumstances when interpreting the contract only if the contract's words are ambiguous. ${ }^{165}$ The source of intrinsic ambiguity is the text of the document, viewed only within its four corners. Therefore, the cognitive task involved in identifying an intrinsic ambiguity is that of interpreting the words of the document based solely on knowledge of the relevant language, the meaning advanced by the parties, and common sense. As Burton states, "No extrinsic evidence is needed to see

\footnotetext{
${ }^{161}$ This rule seems to be affected by logical circularity, as the parol evidence is relied upon to determine the applicability of a rule that excludes the very same parol evidence. However, the circularity is only apparent when one considers that the extrinsic evidence can be use both as evidence of the parties' intention to consider a written document as integrated and as evidence to establish the meaning of a contractual term. It is in the first sense that parol evidence is used for the purpose of determining the applicability of the parol evidence rule.

162 Waddams, 1991, supra note 156 at 386.

${ }^{163}$ Burton, supra note 19 at $81-82$.

${ }^{164}$ This is a well-settled principle in the Canadian common law of contract. See e.g., Hi-Tech Group Inc v Sears Canada Inc, 52 OR (3d) 97, [2001] O.J. No. 33 at para 18; Elias Family Trust v Western Financial Group Inc, [2017] MJ no 31 at para 102 (MBCA) [Elias].

165 This position was adopted by the SCC in Eli Lilly \& Co v Novopharm Ltd, [1998] 2 SCR 129, [1998] 2 RCS 129. It was overruled by Sattva; see Hall, supra note 5 at 25.
} 
an intrinsic ambiguity."166 The identification of intrinsic contractual ambiguity is interpretive in nature, and the trial judge has no particular advantage over appellate courts. Whether a written agreement is intrinsically ambiguous is a question of law for the trial court to determine.

As a result of the contextualist turn in contractual interpretation, a well-established principle in current Canadian common law mandates courts consider the background facts of the contract regardless of any finding of ambiguity on a plain reading of the language of the contract. ${ }^{167}$ Indeed, a few appellate courts have taken a further step and stated that a finding of ambiguity can be properly reached only if the factual matrix has first been considered. ${ }^{168}$ From this perspective, the source of contractual ambiguity is to be found in the context of the agreement. The shift from textualism to contextualism in contractual interpretation has been paralleled by a shift from intrinsic to extrinsic ambiguity. Ambiguity may result not from the face of the contract, but from extrinsic evidence applied to the meaning of its text. This has changed the nature of the cognitive task underlying the ambiguity issue. To determine whether the contract is ambiguous in light of the surrounding circumstances, the judge must make certain factual findings, including the nature of the contractual relationship, the purpose of the agreement, the customs of the industry in which the contract was created, and any evidence of negotiations between the parties. However, this is not to say the issue is one of fact reviewed on a deferential standard on appeal. ${ }^{169}$

The activity of ascertaining the surrounding circumstances must be separated from that of drawing legal inferences from them. The former exercise is a matter of fact, at least to the extent it involves the ascertainment of empirical facts, such as negotiations between the parties, customs of the relevant industry, or antecedent oral agreements. The trier of fact determines the truth or falsehood of existential statements concerning the surrounding circumstances. Once the surrounding circumstances have been ascertained, the task of identifying any relevant contractual ambiguity is yet to be performed. The judge must use these factual findings as an interpretive aid to determine the plausibility of the various meanings proffered by the parties. The judge's focus is on the degree of reliability of interpretive sentences concerning the meaning of the words of the contract in light of the facts of the case, not the truth or falsehood of existential statements concerning these facts. It is conceptually troubling that the contextualist approach transforms the interpretive exercise into a fact-specific one. The contextualist approach entails a shift from intrinsic to extrinsic ambiguity, which certainly increases the importance and

\footnotetext{
${ }^{166}$ Burton, supra note 19 at 107.

${ }^{167}$ E.g., Eco-Zone Engineering Ltd v Grand Falls-Windsor (Town), 2000 NFCA 21, [2000] N.J. No. 377 at para 10; King, supra note 22 at paras 69-70; Sattva, supra note 1 at para 46; Fontaine et al v Canada (Attorney General) et al, 2014 MBCA 93, [2014] M.J. No. 290 at para 43; Directcash Management Inc v Seven Oaks Inn Partnership, 2014 SKCA 106, [2014] S.J. No. 580 at para 13; Shewchukv Blackmont Capital Inc, 2016 ONCA 912, [2016] O.J. No. 6190 at para 39; IFP Technologies (Canada) Inc v EnCana Midstream and Marketing, 2017 ABCA 157, [2017] A.J. No. 666 at para 82 [IFP Technologies].

${ }_{168}^{1 F P}$ Technologies, supra note 167 at para 113.

${ }^{169}$ Current case law is consistent with this conclusion. Courts of appeal have established that an ambiguous contract is reviewed for palpable and overriding error; see Bighorn (Municipal District No. 8) v Bow Valley Waste Management Commission, 2015 ABCA 127 at para 9, 599 AR 395.
} 
complexity of the fact-finding role of the judge, but the existence of ambiguity remains an interpretive issue concerning the substance of the written instrument.

After considering the elements of the factual matrix (as previously determined in the judgment of fact), the judge may decide the language of the contract is ambiguous; that is, more than one interpretive sentence, among those alleged by the parties, can ascribe a reasonable meaning to the words of the contract. Alternatively, the judge may reach the conclusion that the contract is unambiguous, as it is has only one reasonable meaning. In both cases, the determination of ambiguity is interpretive in nature and is considered a matter of law that appellate courts review without showing any deference to the trial judge's findings. The judge must provide reasons justifying the conclusion why the interpretation alleged by the parties ascribes a plausible meaning to the words of the contract in light of the surrounding circumstances. Because this is a legal matter, the court of appeal reviews these reasons on correctness.

This approach is consistent with the Manitoba Court of Appeal ruling in Elias Family Trust $v$ Western Financial Group Inc, holding that the trial judge failed to apply the correct test to determine legal ambiguity. ${ }^{170}$ The court stated, "Difficulty in construction, without more, does not give rise to an ambiguity." "171 At trial, the judge gave no explanation of why the disputed contractual provision was ambiguous. ${ }^{172}$ In so doing she committed "an extricable question of law" which is "reviewed on the basis of correctness." "173 Similarly, the Ontario Court of Appeal in Amberber v IBM Canada Ltd ${ }^{174}$ held the motion judge committed an extricable error of law reviewable on a correctness standard when "she strained to find an ambiguity where none reasonably exists."175

\section{RESOLVING CONTRACTUAL AMBIGUITIES}

If after considering the elements of the factual matrix (as previously determined in the judgment of fact), the judge determines that the language of the contract is unambiguous, the judge decides the interpretive issue by giving the unambiguous contract its unambiguous meaning. If she finds the contract offers more than one reasonable meaning, she must then resolve the ambiguity and determine the meaning of the words of the contract in light of the factual matrix. Whether this resolution involves questions of fact or questions of law depends on a variety of factors. Although it is not possible to provide a comprehensive analysis of all possible scenarios, a brief examination of the most common situations reveals many aspects of the process of contractual interpretation require no fact-finding.

\footnotetext{
${ }^{170}$ Elias, supra note 164.

${ }^{171}$ Ibid at para 102.

${ }^{172}$ The court quotes the trial judge, "I cannot say that the meaning of each of those three . . clauses is clear and unambiguous." Ibid at para 188.

${ }^{173}$ Ibid at para 100.

${ }^{174} 2018$ ONCA 571, [2018] O.J. No. 3370 [Amberber].

${ }^{175} \mathrm{Ibid}$ at para 65 .
} 


\section{Choosing the interpretive approach}

The contextualist approach established in Canadian common law requires courts to consider the relevant surrounding circumstances regardless of whether a plain reading of the language of the contract reveals any ambiguity. Based on this normative premise, the trial judge that fails to consider the factual matrix based on the lack of intrinsic ambiguity commits an error of law to be reviewed on the correctness standard. A few appellate courts have expressly recognized this point.

For example, in Puri Consulting Limited $v$ Kim Orr Barristers ${ }^{176}$ the Ontario Court of Appeal held that failing to consider the factual matrix of a contract amounts to a reversible error of law. At issue in Puri was the interpretation of an offer to settle. ${ }^{177}$ The offer proposed to settle upon payment of the stipulated amount "in full and complete satisfaction of Puri's claim." The respondent accepted the offer several months later and subsequently paid Puri the full amount. Puri asserted they were entitled to additional compensation and brought a motion to enforce the settlement. The issue before the motion judge was whether the accepted offer provided for the disposition of cost. The motion judge found the offer unambiguous, asserting the words "full and complete satisfaction" meant the offer was inclusive of costs and on this basis dismissed the motion.

The relevant factual matrix included Rule 49, the timing of the offer, and its acceptance. ${ }^{178}$ The Court noted both parties were aware that the later the acceptance of an offer to settle, the greater the costs paid by the offeror. These circumstances do not favour the respondent's interpretation of the offer, as rather than acting as an incentive to encourage early settlement, the value of the offer would decline over time as the parties approached their trial date and the appellant's legal costs increased. The motion judge failed to interpret the offer in the relevant context of the litigation and Rule 49, and so appeal was granted and the respondent ordered to pay the appellant its costs. ${ }^{179}$ One commentator observed that the decision in Puri shows Sattva, though generally mandating a high degree of appellate deference, can nonetheless result in little or no deference to a judge who fails to consider the factual matrix when interpreting a contract. $^{180}$

\section{Determining the Factual Matrix}

Once the judge adopts the contextualist approach to contract interpretation, she must determine the elements that may be considered within the factual matrix. This is often critical to the task of resolving contractual ambiguities, as the parties' objective intentions may change significantly depending on which circumstances are taken into account when interpreting the contract. Hence, it comes as a surprise that appellant parties often submit that the trial judge erred in performing this preliminary task. A few courts of appeal have

\footnotetext{
1762015 ONCA 727, [2015] OJ no 5649.

${ }^{177}$ Puri served the offer under Rule 49 of the Rules of Civil Procedure.

${ }^{178}$ See supra note 177.

${ }^{179}$ See also IFP Technologies, supra note 167 at para 113.

${ }^{180}$ Mark Gelowitz, Puri Consulting Limited v. Kim Orr Barristers PC: Ontario Court of Appeal Overturns Motion Judge for Failing to Consider "Factual Matrix", of Settlement Offer (2015), online: Osler. <https://www.osler.com>. See also Sopinka, supra note 11 at 125 n 189.
} 
characterized the trial judge's determination of the factual matrix as a question of fact. ${ }^{181}$ However, this proposition is objectionable, as it does not properly distinguish between different tasks involved in determining what constitutes relevant surrounding circumstances. To identify the various steps the judge undertakes, one must first understand that the factual matrix is a normatively evaluated fact.

According to a well-settled definition, the factual matrix includes the set of circumstances that was or reasonably ought to have been within the common knowledge of the parties at the time of execution of the contract. ${ }^{182}$ The factual matrix is an evaluatively determined fact that encompasses anything recognized by a reasonable person as affecting the way in which the language of the document would have been understood. ${ }^{183}$ That is, the normative criterion of reasonableness ultimately defines the boundaries of what constitutes the relevant factual circumstances surrounding the formation of the contract. This normative nature has significant implications as to the structure of the cognitive task performed by the judge in determining the factual matrix. The existential statement concerning an evaluatively determined fact consists of both a descriptive statement and a value judgment; within the value judgment two further steps must be identified: the choice of the axiological criteria according to which facts must be assessed and the value judgment about the individual fact. These considerations suggest the proper characterization of the judge's determination of the factual matrix must include three steps: 1) the determination of the empirical facts surrounding the formation of the contract; 2) the choice of the evaluative criterion for determining what properly constitutes a factual matrix for the purposes of dispelling contractual ambiguities; and 3) the determination of what properly constitutes the factual matrix in the particular case at dispute. The conceptual framework developed in Section III helps illuminate these distinctions and provides guidance on properly characterizing different types of errors the trial judge may incur.

To determine the factual matrix, the judge must evaluate the truth or falsehood of the existential statements concerning the empirical facts surrounding the formation of the contract; the judge relies on an assessment of empirical evidence offered by the parties. This factual matter should be reviewed on a deferential standard on appeal. The judge must then decide which of these facts properly constitute the factual matrix. This is a conceptually distinct task that involves selecting facts that may serve as interpretive aids in determining the meaning of the words of the contract. To make this assessment, the judge must first identify a selecting criterion and then apply it to the particular facts of the case. The choice of the selecting criterion is a function of the theory of contractual interpretation that is embedded in the relevant legal framework; therefore, it is guided by the legal-normative context in which the judge operates. The choice of criterion used to create a factual matrix is a matter of law that appellate courts review without showing deference to the trial judge's choice.

\footnotetext{
${ }^{181}$ IFP Technologies, supra note 167 at para 83.

${ }^{182}$ See the case law mentioned supra notes 26 and note 141.

${ }^{183}$ Sattva, supra note 1 at para 58.
} 
According to current Canadian case law, this criterion is the reasonable common knowledge of the parties at the time of the execution of the contract. The trial judge who constructs a factual matrix inconsistent with this objective definition commits an error of law to be reviewed on correctness standard. When the selecting criterion is determined, the judge must apply it to the concrete case at hand to determine which specific factual elements reasonably ought to have been within the common knowledge of the parties. The judge must state the inference that leads from the general evaluative premise (provided by the selecting principle) to the determination that a specific element constitutes a relevant surrounding circumstance). The failure to state this inference constitutes an error of law to be reviewed on correctness standard.

The decision of the Ontario Court of Appeal in Deslaurier Custom Cabinets Inc $v$ 1728106 Ontario Inc provides a useful example of the various tasks involved in determining the factual matrix. ${ }^{184}$ The parties were a landlord and a tenant under a lease. After a fire at the leased premises, the tenant brought claim against the landlord for losses under the lease. The issue at trial was the interpretation of a structurally ambiguous lease agreement. The ambiguity involved incoherence between the indemnification clauses contained in the lease. To dispel the contractual ambiguity, the motion judge admitted as extrinsic evidence leases for other units in the same building and granted damages against the landlord.

The Court of Appeal held that the motions judge had erred in admitting extrinsic evidence of other leases and relying on it to interpret the lease. Relying on Sattva, the court stated relevant extrinsic evidence in contractual interpretation "should consist only of objective evidence of the background facts at the time of the execution of the contract." Here, the trial records did not establish that the other leases were within the knowledge or ought to have been within the knowledge of both parties prior to entering into the lease. ${ }^{185}$ The trial judge "did not explain the basis for her admission of the challenged extrinsic evidence."186

The court deferred to the motion judge's factual findings; its decision was based on the facts outlined in the motion judgment's records. In addition, the court clearly identifies the criterion for selecting the circumstances relevant to deciphering the meaning of words contained in the factual matrix. According to the court, the motion judge failed in not applying this criterion to the facts of the case; it noted, "[T] he record before this court does not establish that the admissibility prerequisite set out in Sattva was satisfied in this case." ${ }^{187}$ This failure to state the inference that enabled the judge to determine the other leases were in the objective knowledge of the tenant is considered an extricable error of law. This line of reasoning exemplifies two points emphasized throughout this paper. First, the contextualist approach does not necessarily require fact and legal principles to be inextricably intertwined in contractual interpretation. Second, appellate courts react to Sattva's overgeneralization by developing exceptions and extricable errors of law,

\footnotetext{
${ }^{184} 2017$ ONCA 293 at para 74 [Deslaurier]

185 Ibid at para 77.

${ }^{186}$ Ibid.

${ }^{187}$ Ibid at para 77.
} 
confirming the standard of appellate review of a contractual interpretation case is flexible and depends on the nature of the issue being considered. ${ }^{188}$

\section{Ascribing meaning to the language of the contract}

Once the judge outlines the scope of the factual matrix, she determines the meaning of the relevant contractual language in light of the admitted extrinsic evidence. The first step in ascribing meaning to relevant linguistic expressions is interpretation in abstract. The judge ascribes a meaning to the factual predicate of the relevant prescriptive sentence (for example, a contractual provision) by determining the intension of the relevant predicates without reference to the particular case. The determination of the intension of terms is not essentially a factual exercise; both the input and the mode of reasoning are legal in nature. The judge applies well-established principles of construction to identify the attributes that define classes of cases. Therefore, interpretation in abstract must be regarded as a legal matter that appellate courts review without showing deference to the trial judge's findings.

With respect to contractual interpretation, the question arises as to whether the nature of the intension problem changes in light of the specific goal of the interpretation process. One might argue that interpretation in abstract becomes a factual exercise, because to determine the intension of a factual predicate in a contractual provision one must reconstruct the intention of the parties at the moment of contract formation. However, the factual or legal nature of contractual interpretation is a function of the theory of contractual interpretation. Where contractual interpretation is based on the ascertainment of the empirical intent of the parties as proven by testimony, it is considered a question of fact and the deferential standard applies. Where contractual interpretation is aimed at determining what the parties objectively said from the standpoint of the law, it is to a large extent a legal exercise.

One could still object that in drawing legal conclusions as to what the parties mutually intended, the trial judge undertakes a context-driven inquiry based on the weighing of evidence; hence, the judge's conclusion regarding the parties' intentions involves an inextricable intertwining of both fact and law. However, the fact-finding exercise used to construct the factual matrix is a distinct activity from the inference-drawing process aimed at determining the meaning to the words of the contract. Once the objective circumstances constituting the factual matrix have been descriptively established (factfinding), the judge uses them as a source of information to generate interpretive sentences concerning the reasonable meaning of the parties' manifestation of intention (lawfinding). In generating these interpretive sentences, the judge must assess the arguments proffered by both parties and offer cogent reasons for choosing the interpretation advanced by either in light of the factual matrix. In so doing, she applies the principles of contractual interpretation, which is properly qualified as a legal matter. Drawing

\footnotetext{
${ }^{188}$ In 1079268 Ontario Inc v GoodLife Fitness Centres Inc, 2017 ONCA 12, [2017] O.J. No. 92, [GoodLife], the Ontario Court of Appeal held that failing to consider critical evidence regarding the surrounding circumstances of the formation of contract is an extricable error of law. In Wade v Duck, 2018 BCCA 176, the British Columbia Court of Appeal concluded the judge erred in interpreting the contract by using the parties' subsequent conduct. According to the court, this amounts to "failure to consider a required element of legal test," a recognized error of law subject to the correctness standard of review (para 32).
} 
interpretive inferences from the factual matrix and ascribing meaning to the disputed words should not be conflated with the determination of the truth or falsehood of existential statements concerning the descriptive elements of the factual matrix (factfinding), or with the application of contractual terms to the concrete facts in issue (application). Even when adopting a contextualist approach to contractual interpretation, the drawing of conclusions regarding the parties' contractual intent remains essentially a legal exercise.

The task of drawing legal inferences from the factual matrix as to what parties intended from an objective standpoint is governed by the fundamental precepts of contractual interpretation. The judge who draws legal inferences from the factual matrix in a manner inconsistent with these principles commits an error of law. In the post-Sattva era, a few appellate courts have recognized this. For example, in Deslaurier, ${ }^{189}$ the Ontario Court of Appeal found the trial judge made an extricable error of law in adopting a construction of the agreement that failed to accord with the governing principles of contractual interpretation. The lease contained both a clause providing that the landlord would indemnify the tenant, and that the tenant would indemnify the landlord. The motion judge considered other leases in the building as extrinsic evidence to guide her in interpreting the lease. These leases, for other units in the same building, contained only a one-way indemnification clause (the tenant would indemnify the landlord); this was deemed a strong indication that, objectively, the parties must have specifically intended to give the tenant some contractual right not granted to the others in the building. The court found this inferential reasoning inconsistent with the principles of contractual interpretation. Even assuming this extrinsic evidence was admissible, the content of other leases in the building could not control the proper interpretation of the lease, because the surrounding circumstances must never be allowed to overwhelm the words of an agreement. ${ }^{190}$ Interpreting the lease in light of other leases in the building would deviate from the text to such an extent that the court would have created a new agreement. The interpretation of a written contractual provision must always be grounded in the text. ${ }^{191}$

Following a remand for reconsideration by the Supreme Court, the Court of Appeal affirmed its original decision, emphasizing the legal nature of the motion's judge error. In particular, the court discussed the issue of the appropriate standard of review in respect to the motion judge's interpretation of the lease. On remand, the tenant submitted that the motion judge's errors did not involve extricable errors of law but, rather, the application of the legal principles of contractual interpretation to a unique set of facts, a question of mixed fact and law. In rejecting the tenant's claim, the court stated the motion judge failed to consider a number of principles relevant to the interpretation of the lease. ${ }^{192}$ The court commented, "The goals of certainty, clarity and consistency in the law dictate that missteps in the identification of controlling legal principles be characterized as questions of law subject to correctness review."193

\footnotetext{
189 Supra note 184.

${ }^{190}$ Ibid at para 79.

${ }^{191}$ Ibid

192 Ibid at para 75 .

${ }^{193}$ Ibid at para 24.
} 
This approach was confirmed in Amberber, ${ }^{194}$ where the Court held, "Failure to read a disputed contract as a whole is a question of law that is extricable from a finding of mixed fact and law. $" 195$ In Amberber, an employee brought a wrongful dismissal claim against his former employer. When added together, the working notice and the termination payment provided by the employer satisfied the entitlement under the termination clause in the parties' employment agreement. However, the employee argued the termination clause failed to rebut the common law presumption of reasonable notice of termination. Under Ontario law, an employee dismissed without cause is presumptively entitled to reasonable notice of the termination, unless the parties agree to contract out of the reasonable notice period and the intention to displace the common law is expressed unambiguously. ${ }^{196}$ According to the motion judge, the termination clause was ambiguous. She resolved this ambiguity in favour of the employee, in accordance with the principle of contra proferentem. The Court of Appeal allowed the plaintiff's appeal and reversed the motion judge's decision. The court felt the individual sentences of the clause should not have been interpreted on their own, but rather read as a whole. When read as a whole, there could be no doubt as to the clause's meaning. The fundamental error was that the motion judge "subdivided the termination clause into what she regarded as its constituent parts and interpreted them individually." 197 In so doing, she failed to apply well-established principles of construction, thereby committing an extricable error of law reviewable on a correctness standard.

Finally, in 1079268 Ontario Inc v Goodlife Fitness Centres Inc, ${ }^{198}$ the Court of Appeal for Ontario stated that failing to consider critical evidence about the surrounding circumstances of the formation of a contract constituted an extricable error of law. The principal issue was whether the basement of the building was included in the premises. The lease agreement contained two contradictory clauses regarding the definition of the total area to be leased. One clause defined the premises as "the entire property"; as "property" was described as the development situated on the land, the tenant interpreted this as meaning the entire building, including the basement. Another clause referred to the "rentable area of premises" as less than that of the whole premises and omitted the basement in the description. The landlord claimed the wording of the lease clearly excluded the basement. To resolve the contractual ambiguity, the trial judge referred to several of the draft leases exchanged by the parties during the negotiation process and concluded the basement was not included in the lease.

The Ontario Court of Appeal overturned the trial judge's decision, pointing out key correspondence between the parties' lawyers that took place early in the negotiations was not considered. This correspondence made clear the parties' intention to lease the entire premises, including the basement. Of the basement kitchen, the tenant's lawyer wrote, "This space will now become part of the Leased Premises." The landlord's lawyer neither confirmed nor rejected the tenant's lawyer assertion concerning the kitchen. However, he

\footnotetext{
${ }^{194}$ Supra note 174

195 Ibid at para 64.

${ }^{196}$ Such an agreement is enforceable if it does not violate the employment standards set out in the Employment Standards Act.

${ }^{197}$ Amberber, supra note 174 at para 59.

${ }^{198}$ GoodLife, supra note 188.
} 
deleted the provision excluding the kitchen from the leased space from the next draft of the lease, and the provision was not present in the final draft. Several provisions from subsequent drafts of the lease confirmed the conclusion that the lease was for the entire premises, including the basement. Although the trial judge acknowledged the deletion of these provisions, she did not consider their deletion in the context of the exchange of correspondence relating to the agreement. In so doing, the judge "failed to interpret the lease having regard to the circumstances as a whole."199 The result was an interpretation of the lease inconsistent with the intention of the parties. The court expressly characterized the trial judge's failure to consider critical evidence as an error of law reviewable on a correctness standard. ${ }^{200}$

\section{Standard Form Contracts}

In Ledcor, the Supreme Court held that the proper interpretation of a standard form contract is a question of law subject to appellate review on the standard of correctness. ${ }^{201}$ Yet the Court's explanation does not hold up when closely scrutinized. The recognition of the correctness standard for appellate review of the interpretation of standard form contracts is grounded on the conclusion that Sattva's reasons for holding that contractual interpretation is a question of mixed fact and law subject to deferential appellate review "are less compelling in the context of standard form contracts." 202 As the majority explained, for standard form contracts, the surrounding circumstances generally play less of a role in the interpretation process.

There are two apparent weaknesses in this reasoning. First, the idea that the factual matrix carries less weight with respect to standard form contracts is untenable. As Bolieiro observes, "In all contracts, even standard form contracts, the words derive their meaning from the context, including 'the purpose of the contract, the nature of the relationship it creates, and the market or industry in which it operates." "203 Second, the activity of ascribing meaning to the words of the agreement is legal in nature, independent of the complexity of the extrinsic evidence the judge must consider to interpret the contract. The task of drawing legal inferences from the factual matrix is distinguished from that of descriptively establishing the facts that constitute the factual matrix. Hence, the legal nature of the interpretive exercise is not a function of how much weight the factual matrix carries in a given typology of contract. The recognition of the correctness standard of appellate review for standard form contracts should not be based on the diminished importance of the factual matrix for this type of contract; rather, the reason for deference must be found in the inherently legal nature of the interpretive exercise.

The preceding considerations suggest the diminished role of the factual matrix is not a justification for applying the correctness standard on appeal. This point is recognized in recent decisions of the Ontario Court of Appeal. For example, in Biancaniello v DMCT

\footnotetext{
199 Ibid at para 26.

${ }^{200}$ Ibid.

${ }^{201}$ Ledcor, supra note 2 at para 24.

${ }^{202}$ Ledcor, supra note 2 at para 26.

${ }^{203}$ Bolieiro, supra note 11 at 5 (quoting Ledcor at paras 30-31 and 106-108). See also Hall, supra note 5 at 152.
} 
$L L P,{ }^{204}$ the court applied the correctness standard on an appeal involving the interpretation of a negotiated contract. Prinova Technologies and DMCT had signed a mutual release to settle a dispute over unpaid legal fees DMCT charged to Prinova for consulting services. The release was broadly worded; it referred to "all claims arising from any and all services provided. Years later, Prinova discovered DMCT had provided negligent advice during the period covered by the release. The issue was whether the release applied to the unanticipated claim. Both the motion judge and the divisional court found the general wording of the release could not bar a claim the parties did not know existed. Interestingly, in the judgment before the divisional court the parties agreed the issue was a question of mixed fact and law, and the appropriate standard of review was therefore one of palpable and overriding error. The Court of Appeal conceded that ordinarily the deferential standard of review would apply. ${ }^{205}$ However, the court observed that the appeal, which concerned the interpretation of a contractual release, raised a question of law to be reviewed on correctness standard. The court reasoned that, although the release was not on a standard form, the issue was one of general public importance as it used language common to many release documents. Ultimately, the court reversed the decision, ruling that the broad wording of the mutual release encompassed unknown claims that existed at the time of the parties' signature.

Focusing on cognitive tasks helps properly characterize the nature of the issue in Biancaniello. To solve the dispute between the parties, the judge had first to establish the intension of the expression "all claims arising from any and all services provided." This is a problem of interpretation in abstract, which requires ascribing a meaning to words without reference to a particular case. The judge needed to determine whether the unknown claim was covered by the phrase, based on its established meaning. This is an issue of generic subsumption, which requires drawing connections between classes of cases (that is, the class of all the claims arising from all services provided and the class of unknown claims). The Court of Appeal and the lower courts diverged on this issue. ${ }^{206}$ However, generic subsumption is a legal matter. ${ }^{207}$ It is therefore appropriate, based on the framework proposed here, to qualify the issue on appeal in Biancaniello as a question of law. This case demonstrates that the precedential value of contractual interpretation is

\footnotetext{
2042017 ONCA 386, [2017] OJ No 2468.

${ }^{205} \mathrm{Ibid}$ at para 20 (The Court observes that because this case involves the interpretation of a release, one may think the standard of review would be the deferential standard normally applicable to the interpretation of negotiated agreements).

${ }^{206}$ The Court clarified, "The Divisional Court held that because the parties were not aware that the accountants had given negligent advice ... the client's claim for negligence did not exist when the release was signed. With respect, this statement constitutes an error of law.... [T] he fact that the claim was not discovered does not mean that it did not exist, nor that it was not discoverable. In fact, it did exist, but came to light only upon being discovered by other accountants four years later." Ibid at para 52.

It is clear the Court of Appeal was not interfering with the lower court's fact-finding (that is, that the claim was unknown to parties). Instead, the question is whether an unknown claim is contained in the broad wording of the release. The Divisional Court adopted the position that an unknown claim is inexistent, while the Court of Appeal asserted the fact that the claim is unknown does not mean that it does not exist. This is a generic subsumption issue and, as such, it is not fact-specific - it should therefore be properly qualified as a question of law.

${ }^{207}$ Based on the determination made by the judge on the generic subsumption issue, she is confronted with the task of individual subsumption. In Biancaniello, this is the determination of whether the negligence issue arising in connection with the service provided during the time covered by the release was an "unknown" claim at the time the release was entered into by the parties. This is a question of fact that was not at dispute.
} 
independent of the relevance of the factual matrix and is associated with whether the disputed issue is a question of interpretation in abstract or generic subsumption.

\section{Mandatory statutory terms}

Another exception to the general principle laid down in Sattva - that contractual interpretation generally involves questions of mixed fact and law-is that the interpretation of an agreement that incorporates mandatory statutory terms is a question of law. ${ }^{208}$ A closer analysis of the case in light of the proposed framework suggests the proliferation of exceptions is artificially induced by the distorted use of the conventional categories of law and fact that characterizes Sattva's categorical approach to contractual interpretation. The interpretation of mandatory statutory terms, like the interpretation of standard form contracts, constitutes no exception to the general principle that the exercise of ascribing meaning to a contractual clause without reference to the particular case is essentially a legal exercise.

CNH Canada involved a dispute over the interpretation of non-renewal clause in a dealership agreement for farm implements, a regulated contract under the Farm Implements Act ${ }^{209}$ and the Dealership Agreements Regulation. ${ }^{210}$ The Agriculture, Food and Rural Tribunal determined the distributor had improperly breached the dealership agreement. The distributor appealed to the Divisional Court, then the Ontario Court of Appeal. Because this statutory right to appeal was limited solely to questions of law, the proper characterization of the nature of the interpretation of the non-renewal clause was of critical importance. The court ruled that whether the dealership agreement provided the distributor with a right of non-renewal is a question of law. The renewal provisions in the Dealership Agreements Regulation are mandatory statutory terms that must be included in dealership agreements; the interpretation of a contract incorporating such terms is of precedential value that transcends the particular factual circumstances of the parties in this dispute. ${ }^{211}$ The separate issue of whether the distributor in the case at hand properly exercised the right of non-renewal is better characterized as a question of mixed law and fact.

The Court of Appeal correctly distinguished between the determination of the meaning of the renewal clause (question of law) and the determination of whether the distributor properly exercised the right of non-renewal according to the proper interpretation of the renewal clause (question of mixed fact and law). However, an understanding of the contractual interpretation process based on the nature of the judicial task suggests a different conceptualization, and therefore a different categorization, of these two separate issues. First, there is no need to emphasize the statutory nature of the right of nonrenewal to conclude its interpretation is a question of law. The determination of the meaning of the renewal clause is a question of law because it involves an exercise of interpretation in abstract of the legal language - that is, an exercise of ascribing meaning to a contractual clause without reference to a particular case. The legal nature of this issue

\footnotetext{
${ }^{208}$ CNH Canada Ltd v Chesterman Farm Equipment Ltd, 2018 ONCA 637, [2018] O.J. No. 3715 [CNH Canada].

${ }^{209}$ RSO 1990, c F4.

${ }^{210}$ O Reg 123/06.

${ }^{211}$ CNH Canada, supra note 208 at para 46.
} 
is not determined by the statutory nature of the term; it depends on the nature of the underlying cognitive task performed by the judge (that is, determining the intension of the factual predicate contained in the renewal clause). Second, the determination of whether the distributor properly exercised the right of non-renewal is a question of fact as it requires the judge to formulate an individual subsumptive sentence. Once the meaning in abstract of the non-renewal clause has been determined, the decision of whether the distributor properly exercised the right of non-renewal requires applying the proper construction of the non-renewal clause to what the distributor actually did.

Based on these considerations, $\mathrm{CNH}$ Canada demonstrates that the proliferation of exceptions to Sattva's general rule is artificially induced by the distorted use of the conventional categories of "law" and "fact."

\section{E APPLYING CONTRACTUAL TERMS}

Once the judge has selected a meaning from those proffered by the parties, she must subsume the concrete case at hand within the class of cases designated by the properly constructed predicates contained in the relevant legal language. This adjudicative step is the primary source of confusion in the case law. In particular, the argumentative style of Sattva generates confusion between the task of "applying the contractual terms to the facts of the case' and that of "applying the principles of contractual interpretation to the process of contractual interpretation."

The Sattva court argued that contractual interpretation consists of ascertaining the objective intent of the parties through the application of legal principles of interpretation; as such, it appears closer to a mixed question, defined in Housen as "applying a legal standard to a set of facts." ${ }^{212}$ However, in the same decision, the Court stated that in contractual interpretation extricable errors of law include "the application of an incorrect principle." 213 It is clear the Court uses "application" to indicate two distinct tasks. One is interpreting the words of the contract consistently with the principles of contractual interpretation; that is, properly applying the canons of construction to the process of ascertaining the intended meaning of the words of the contract. The second is applying the terms of the contract to the facts of the case; that is, subsuming the particular facts of the cases within the class of cases designated by the factual predicate of the relevant contractual provisions.

In the language of the proposed framework, Sattva generated confusion between the intension problem - solved through the process of interpretation in abstract of factual predicates - and the extension problem - solved through the process of subsuming the facts in issue into the factual predicate. Sentences defining the intension of factual predicates generally involve questions of law, while sentences defining the extension of factual predicates may involve either questions of law or questions of fact depending on whether the subsumption is generic or individual. Individual subsumption generally

${ }^{212}$ Sattva, supra note 1 at para 49.

${ }^{213} \mathrm{Ibid}$ at para 53. 
involves questions of fact, as it requires classifying a particular case within the class designated by the meaning of the term. Generic subsumption involves establishing a relationship between classes of cases. In this sense, it is an interpretive exercise and may be thought of as involving questions of law.

Table 4. The proposed categorization of contractual interpretation issues

\begin{tabular}{|c|c|}
\hline Questions of Fact & Questions of Law \\
\hline $\begin{array}{l}\text { - Individual subsumption involved in the } \\
\text { determination of integration } \\
\text { - Determination of the empirical facts } \\
\text { surrounding the formation of the contract } \\
\text { - Consideration of extrinsic evidence for the } \\
\text { purposes of determining whether the contract } \\
\text { is integrated } \\
\text { Determination of what properly constitutes } \\
\text { the "factual matrix" in the particular case at } \\
\text { dispute } \\
\text { Individual subsumption of the individual fact } \\
\text { in issue into the contractual predicates when a } \\
\text { gap in empirical knowledge is involved }\end{array}$ & $\begin{array}{l}\text { - Identification of the principles governing the } \\
\text { - } \text { parol evidence rule } \\
\text { - } \\
\text { - Ideneric subsumption involved in the } \\
\text { - } \text { Identification of extrinsic ambiguity } \\
\text { - Choice of the interpretive approach } \\
\text { properly constitutes the "factual matrix" for the } \\
\text { purposes of dispelling contractual ambiguities } \\
\text { Interpretation in abstract of the intension of } \\
\text { contractual terms used } \\
\text { Inference-drawing from the surrounding } \\
\text { circumstances to the meaning of the contract's } \\
\text { text } \\
\text { Generic subsumption of the fact in issue into the } \\
\text { contractual predicates } \\
\text { Individual subsumption of the individual fact in } \\
\text { issue into the contractual predicates when a gap } \\
\text { in semantics recognition is involved }\end{array}$ \\
\hline
\end{tabular}

\section{Conclusions}

This paper develops a methodological framework for distinguishing between questions of fact and questions of law in contractual interpretation and determining the appropriate degree of deference to be accorded by the appellate court to the trial judge's contract interpretation. The proposed methodology comprises two steps: 1) the identification of the cognitive task performed by the judge when adjudicating the contended issue; and 2) the assessment of the relative advantage of alternative adjudicating actors in performing that cognitive task. Based on this methodological premise, it is argued that the general characterization of contractual interpretation as a question of mixed fact and law reviewable on a deferential standard lacks rigorous analytical foundations and ultimately fails to guide the choice of the appropriate standard of appellate review of decisions interpreting contracts.

Certain difficulties associated with Sattva's deferential standard trace back to Housen's categorization of questions. ${ }^{214}$ First, Housen fails to recognize the fundamental distinction

${ }^{214}$ Hall, supra note 5 at 152. 
between facts descriptively determined and facts evaluatively determined, overlooking the circumstances under which fact-finding may involve questions of law when facts evaluatively determined are involved. Second, Housen fails to appreciate the structural similarity between interpretation in abstract and generic subsumption, thereby according a different degree of deference to decisions involving similar judicial cognitive processes. Finally, Housen fails to appreciate the cognitive differences between generic and individual subsumption, thereby according a similar degree of deference to different judicial cognitive processes.

Other difficulties associated with Sattva's deferential standard stem directly from the troubling theoretical assumptions underpinning its line of reasoning. First, the fact that the obligations arising from a contract are limited to the interest of the particular parties does not support the contention that contractual interpretation issues have limited precedential value. The interpretation of the words of the contract requires the judge defining the intension of relevant predicate expressions designing classes of cases. This leads to the formulation of interpretive sentences that may be of precedential value for future similar cases. Second, there is a conceptual tension between the objectivist approach to contractual interpretation underlying the Canadian common law and the qualification of contract interpretation as a question of mixed fact and law reviewable on a deferential standard on appeal. Under the objectivist framework adopted in Sattva, the goal of contractual interpretation is to determine parties' objective intent in light of the relevant context, not to ascertain the parties' subjective intent at the time of contract formation. The cognitive task performed by the judge is to assess the reliability of interpretive sentences and ascribe meaning to the relevant predicate expressions, not to assess the truth or falsehood of existential descriptive statements concerning the parties' empirical intent. Therefore, the meaning-ascribing activity is hermeneutic in nature and properly qualified as a legal matter. Third, and relatedly, there is no logical connection between the juridical relevance of the factual matrix in contractual interpretation and the qualification of contractual interpretation as a question of mixed fact and law. Under the objectivist framework, the judge does not use context as circumstantial evidence of the empirical intent of the parties, instead using context as an interpretive aid for ascribing meaning to the relevant legal language contained in the contract's text. The inferences drawn from the surrounding circumstances inform the interpretive process through which the interpreter ascribes meaning to the words of the agreement and should therefore be properly qualified as legal. Finally, by holding that contractual interpretation generally involves questions of mixed fact and law, the Supreme Court fails to properly appreciate the heterogeneity of issues arising in contractual interpretation disputes. Sattva misleadingly refers to the process of contractual interpretation as an indistinct whole, without properly distinguishing its various components.

In addition to these theoretical weaknesses, the new jurisprudential trend seems doomed to fail at the practical level. First, the general deferential rule fails to meet the increasing demand for appellate review generated by the contextualist adjudicatory style. Second, the conceptual indeterminacy of the notions of mixed questions and extricable errors of law generates uncertainty regarding the standard of appellate review and ultimately generates case law of an ad hoc nature, plagued by uncertainty and incoherence. This is 
confirmed by the growing number of extricable errors of law identified by appellate courts in the aftermath of Sattva. Finally, the general deferential standard does not benefit appellate courts. In fact, the difficulty of identifying extricable questions of law in contractual interpretation disputes does not relieve a reviewing court of the necessity of properly characterizing the nature of the interpretation question at issue.

Based on these theoretical and practical considerations, it is argued that the determination of the appropriate standard of appellate review of a contractual interpretation case should be based on a careful examination of the relative competence of trial judges and appellate courts in performing the specific cognitive task required by the narrow issue at dispute. It is suggested the proper characterization of the nature of contractual interpretation issues should take into account four points. First, the cognitive task performed by the judge in the fact-finding differs significantly depending on whether the facts in issue are evaluatively determined or descriptively determined. Second, value judgments arise in the inference-drawing process taking place during the ascertainment of facts based on circumstantial evidence. Third, an interpretive exercise is involved both in interpretation in abstract and generic subsumption. Indeed, both refer to classes of cases and require defining the intension of factual predicates. Fourth, the nature of the cognitive task involved in individual subsumption depends on whether the judge addresses a gap in empirical knowledge (question of fact) or a gap in semantic recognition (question of law).

Finally, based on these four methodological points, an alternative categorization of contractual interpretation issues has been developed (see Table 4). It has been shown that the proposed categorization is consistent with the list of extricable errors of law identified by appellate courts. The analysis of the various cognitive tasks performed by the judge in the process of contractual interpretation suggests that while certain issues associated with contractual interpretation are factual in nature, others require no fact-finding and are essentially a legal exercise. ${ }^{215}$ Therefore, rather than generalizing the deferential standard of review to all contractual interpretation issues, and relegating correctness review to exceptional cases of extricable errors of law, a more sensible approach would be to distinguish between the various steps involved in the process of contractual interpretation and locate each step at the proper point on the fact-law spectrum. One could object that sorting questions of fact and questions of law in contractual interpretation and applying different standards of review is to ask the impossible of courts of appeal, complicating the appellate task. This paper indicates this is not the case by suggesting a methodological framework for untangling fact from law in contractual interpretation.

\footnotetext{
${ }^{215}$ See Burton, supra note 19 at 119
} 